



\section{Análise de exposições}

Quando falamos em projetos culturais expográficos enaltecemos sua importância como veículo de informações sociais, levando cultura a população e fazendo com que o homem repense a sociedade na qual se insere.

A busca por esse meio de comunicação vem crescendo a cada dia e isso faz com que bons projetos culturais tornem-se cada vez mais escassos.

Propor um bom projeto cultural é, antes de tudo, pensar em como o visitante irá utilizar-se do espaço e dos objetos expográficos e repassar esse conhecimento e os questionamentos levantados para o seu cotidiano.

Para isso, as instituições deverão pensar em projetos que atendam aos mais diversos tipos de públicos-alvo, para que seu leque de aplicações seja o mais amplo possível e, consequentemente, a absorção de ideias e o feedback do público possam ser mais bem aproveitados.

Como exemplo, duas exposições visitadas serão citadas, elencando os aspectostécnicos positivos e negativos delas e, analisaremos por que uma consegue atingir seus objetivos e a outra de certa forma não atinge. Faremos também um levantamento das exposições no circuito atual explicitando os objetivos a serem atingidos.

\subsection{Menas: o errrado do certo, o cert'o do errrado}

Primeiramente, uma das exposições que mais chamaram a atenção no período de pesquisa foi a Menas: o errado do certo, o certo do errado, que ocorreu no Museu da Língua Portuguesa no período de 16 de março a 18 de julho de 2010.

Essa exposição contou com sete instalações que mostravam de forma clara e objetiva ao público como a língua portuguesa sofre mutações em sua forma culta para se adaptar ao cotidiano atribulado e corriqueiro dos dias atuais.

A Menas revela que os "erros" cometidos por nós no dia a dia, normalmente, não ocorrem de forma intencional pois, pelo fato de nossa língua possuir muitas variantes e inúmeras regras gramaticais, o não conhecimento delas faz com que adaptemos alguns termos para que nossa mensagem possa ser compreendida rapidamente.

De forma interativa e lúdica, segue abaixo um resumo das instalações da exposição Menas extraídas do site do Governo do Estado de São Paulo:

\section{- Portas Abertas}

Ao entrarmos no pátio da bilheteria do Museu da Língua Portuguesa trinta banners estavam grafados com diversas frases contendo erros ortográficos registrados no português popularmente falado no Brasil. Portas Abertas é o título desta instalação que, segundo os curadores, tem o objetivo de deixar o visitante "com a pulga atrás da orelha". 


\section{- Óculos}

A segunda instalação é um jogo de placas acrílicas suspensas por cabos de metal que, à primeira vista, sugere ao visitante uma grande bagunça. Um pequeno furo que funciona como leitor óptico pelo visitante coloca ordem nas palavras e formam frases que tem por intuito preparar a mente e quebrar antigas certezas do visitante ao longo da exposição. Abaixo, fotos desta instalação e de como funciona o aparato interativo.

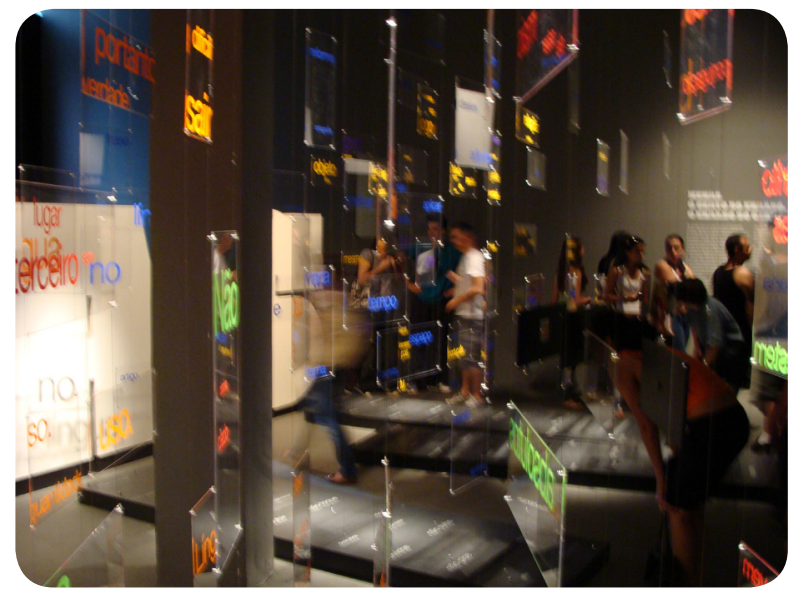

Figura 1. Entrada da exposição Menas com as placas suspensas. À direita podemos notar o visitante agachado para ver pelo leitor óptico a frase em destaque.

Fonte: Acervo dos autores
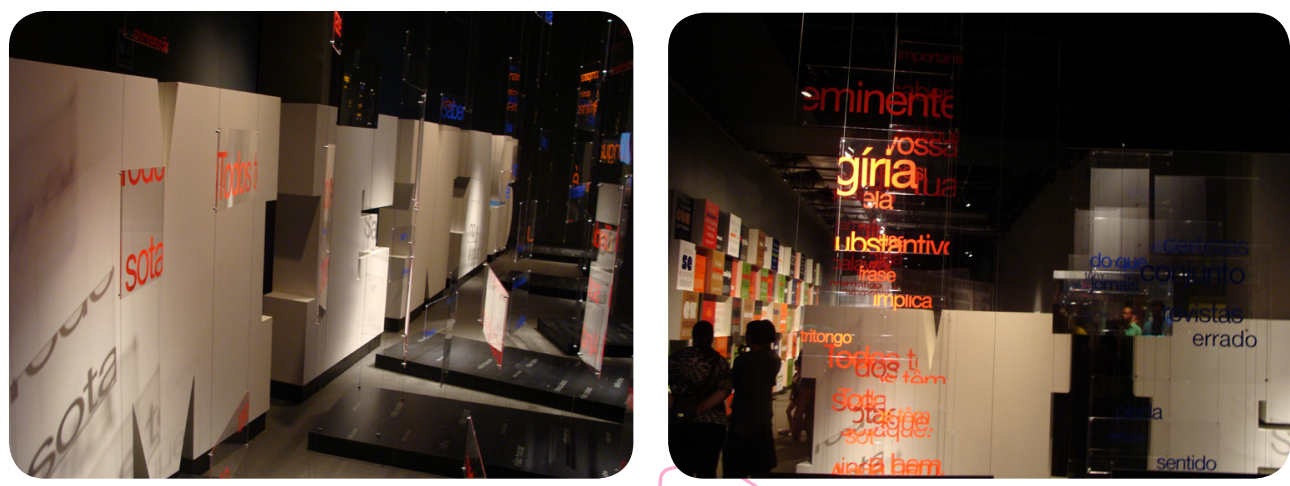

Figuras 2 e 3. Entrada da exposição Menas. Em destaque as placas suspensas.

Fonte: Acervo dos autores
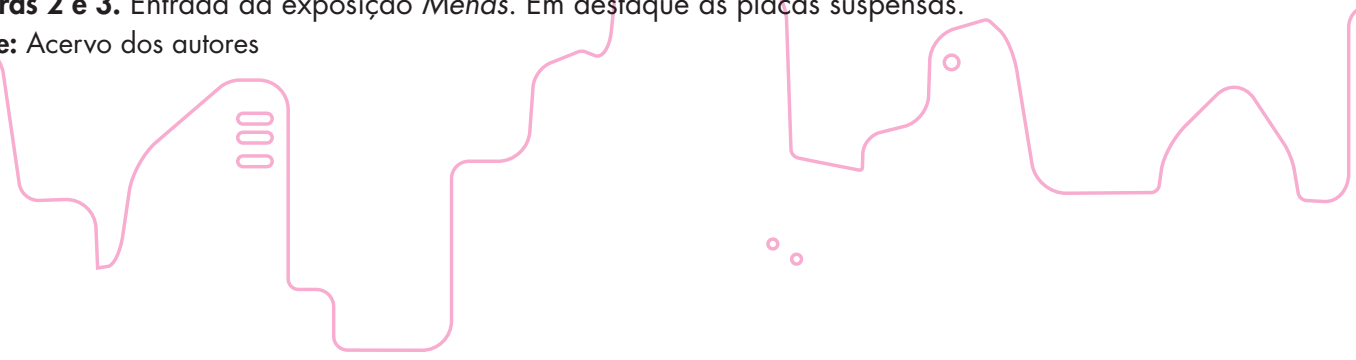

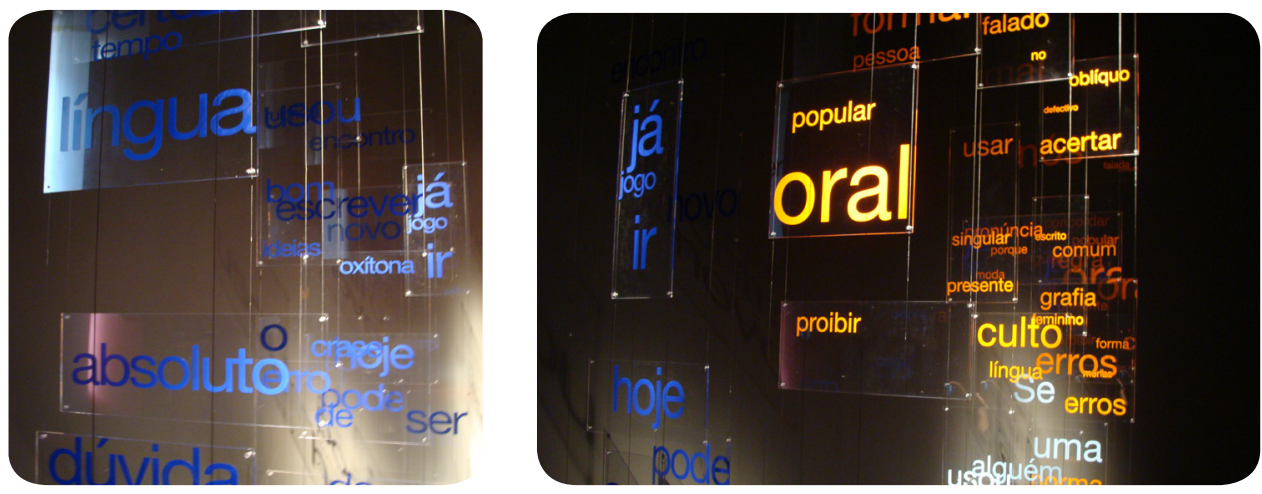

Figuras 4 e 5. Placas de acrílico suspensas na instalação óculos.

Fonte: Acervo dos autores
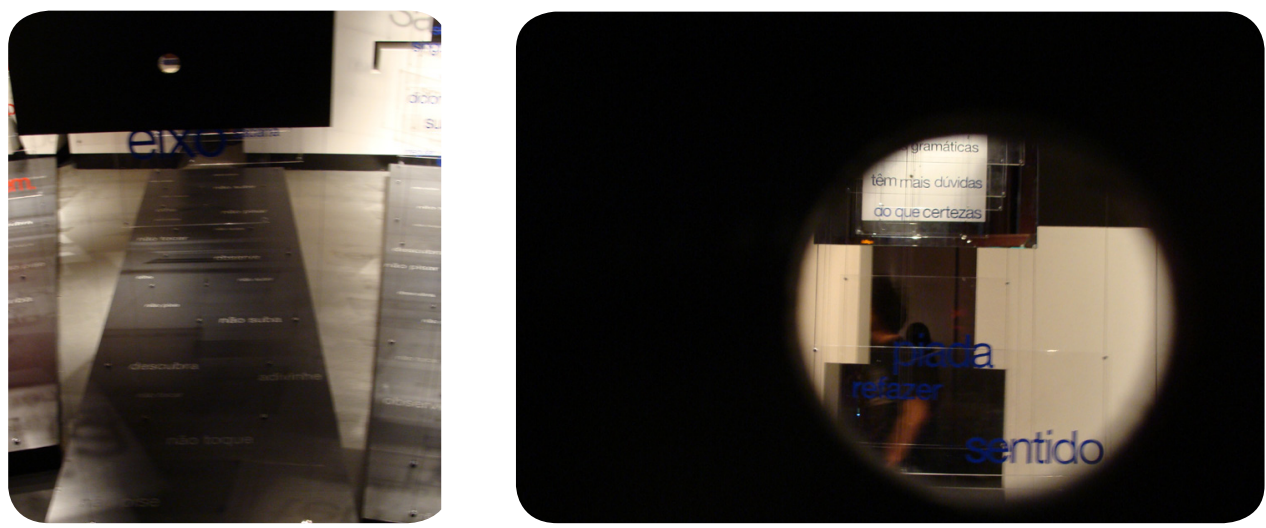

Figuras 6 e 7. Detalhes do leitor óptico.

Fonte: Acervo dos autores

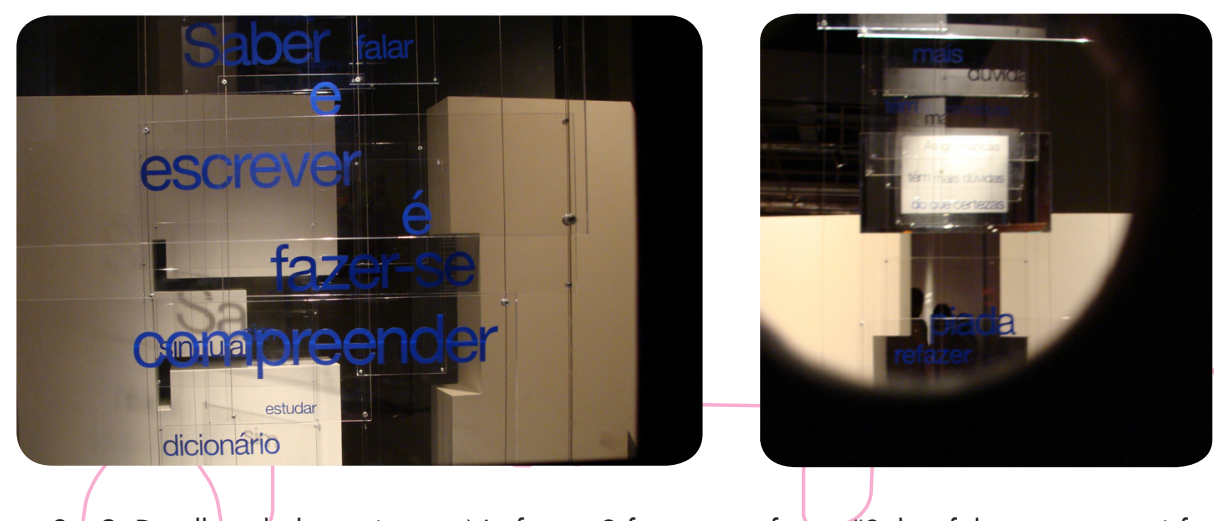

Figuras 8 e 9. Detalhes do leitor óptico. Na figura 9 forma-se a frase: "Saber falar e escrever é fazerse compreender".

Fonte: Acervo dos autores 


\section{- Os 100 erros nossos de cada dia}

Em um grande painel de $3 \mathrm{~m} \times 12 \mathrm{~m}$, foram grafados os 100 erros mais habituais uma seleção de erros lexicais, semânticos, gramaticais e discursivos mais frequentes, que todos nós, por vezes, cometemos. Os comentários que se seguem abaixo de cada erro mostram a motivação estrutural do erro; o que se considera errado hoje já foi considerado certo; a motivação fonética do erro; a ênfase exagerada, etc. $\bigcirc$ intuito é fazer com que o visitante compreenda o porquê do erro, qual a forma correta de ser falado e que ele possa ver a quantidade de nuânces que a língua portuguesa pode ser falada e adaptada.
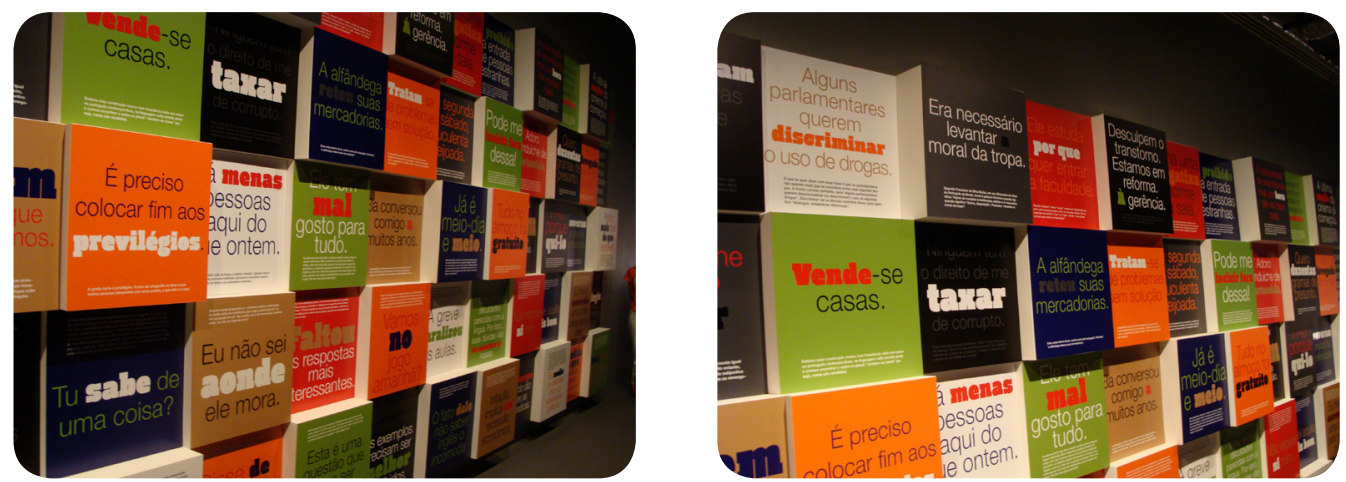

Figuras 10 e 11. $O$ mural com os 100 erros da língua portuguesa.

Fonte: Acervo dos autores.
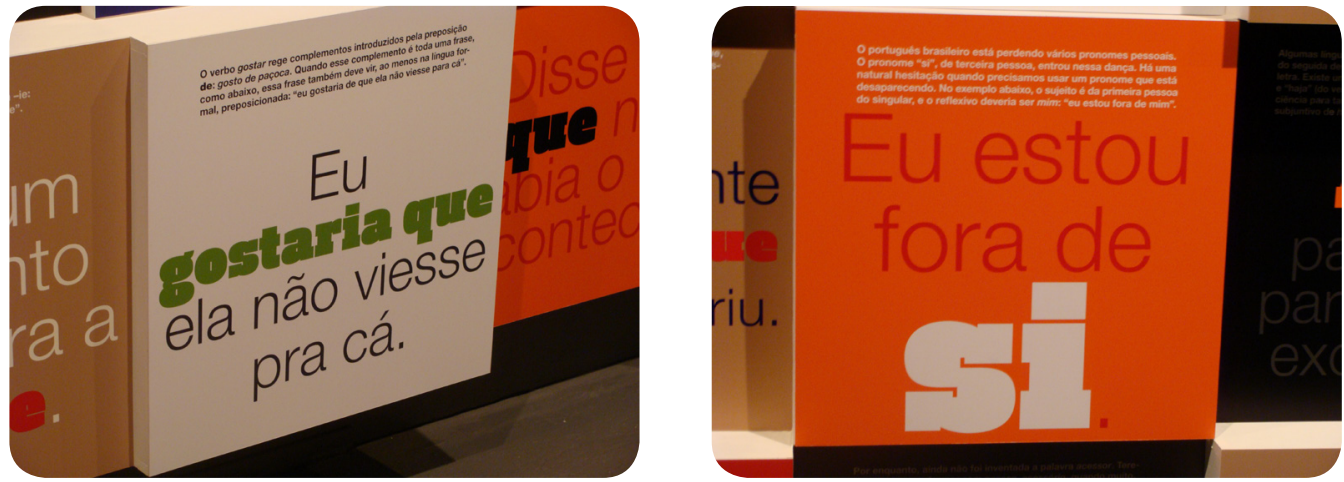

Figuras $12 \mathrm{e}$ 13. Detalhe de alguns dos erros do mural. Em evidência a frase com destaque maior para o erro e, acima, sua explicação.

Fonte: Acervo dos autores.
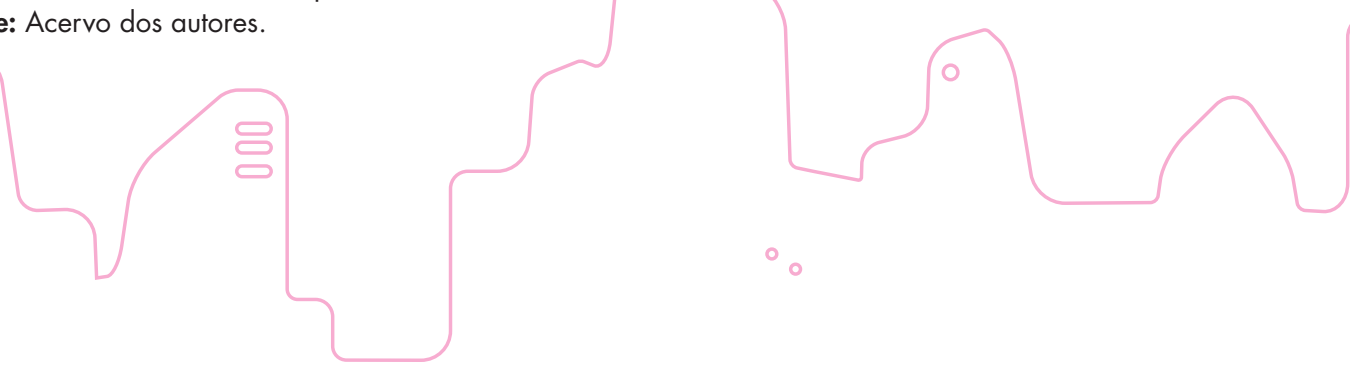


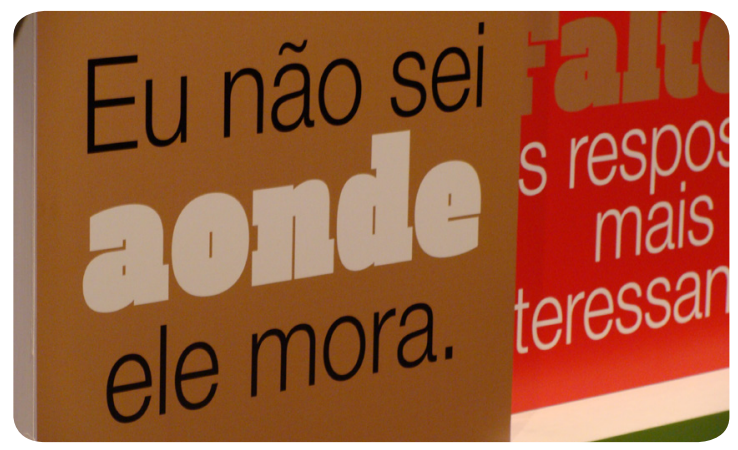

Figura 14. Detalhe de um dos erros aplicados no mural.

Fonte: Acervo dos autores.

\section{- Jogo do certo e do errado}

Essa instalação utilizou nove telas de computador touch screen ligadas em rede. $\bigcirc$ "jogo" proposto era um quiz com 15 perguntas em cada tela. $O$ visitante encontrou uma atividade que desafiaria suas certezas. Entre elas, a que no dia a dia ele encontrará muitas situações em que algo parece estar certo (mas não está) e descobrir outras palavras ou expressões que ele tem certeza de que estão erradas (e, na verdade, não estão). A cada questão correspondem quatro alternativas e o visitante escolhe a que Ihe pareça mais adequada. Imediatamente, o sistema calcula o percentual de visitantes que fizeram a mesma escolha. Na sequência, um comentário explica o fundamento das alternativas. A quantificação percentual de todas as perguntas será computada durante todo o período da exposição.

Figura 15. O visitante utilizando a tela de perguntas.

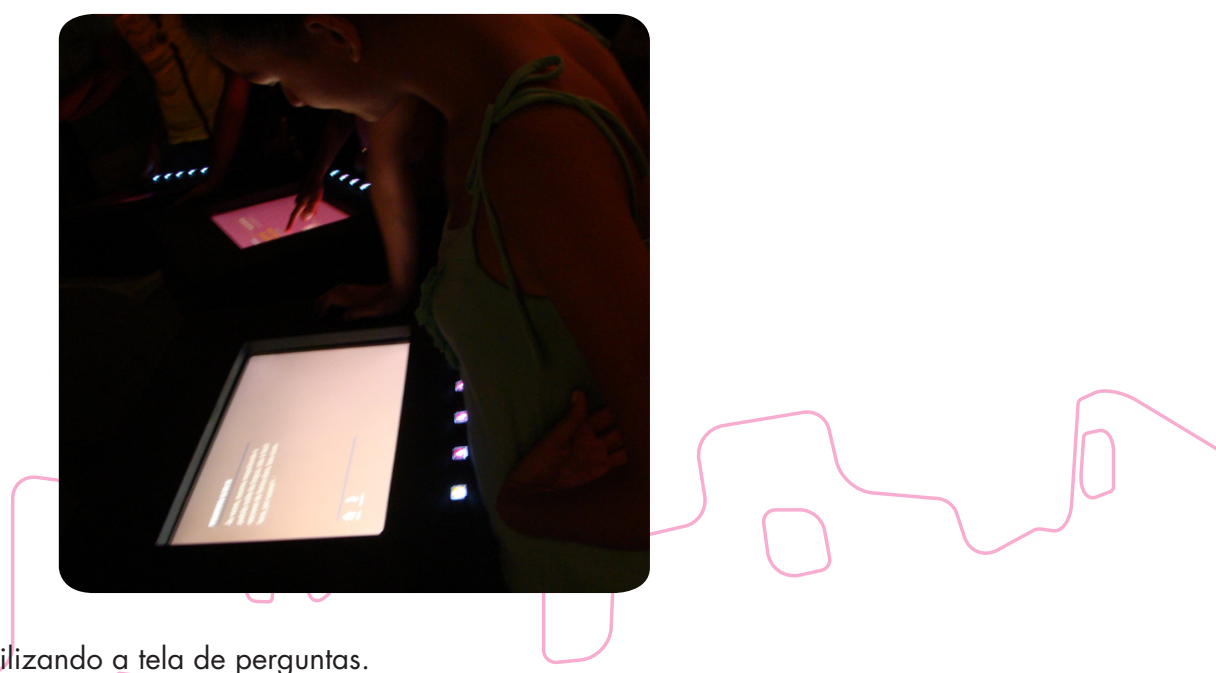

Fonte: Acervo dos autores 


\section{- Biblioteca de Babel}

Essa instalação encerra uma desordem intencional, cujo objetivo foi retratar a língua como de fato ela é. Escritores e compositores se manifestam sobre a língua e sobre a vida, apresentando posições inesperadas e criativas que desarranjam a visão tradicional sobre a língua portuguesa. Daí o título: "Biblioteca" - que supõe a organização, as ideias no lugar, o já sabido; "de Babel" - o avesso disso tudo, a desordem criativa, as ideias provocativas, o não sabido.
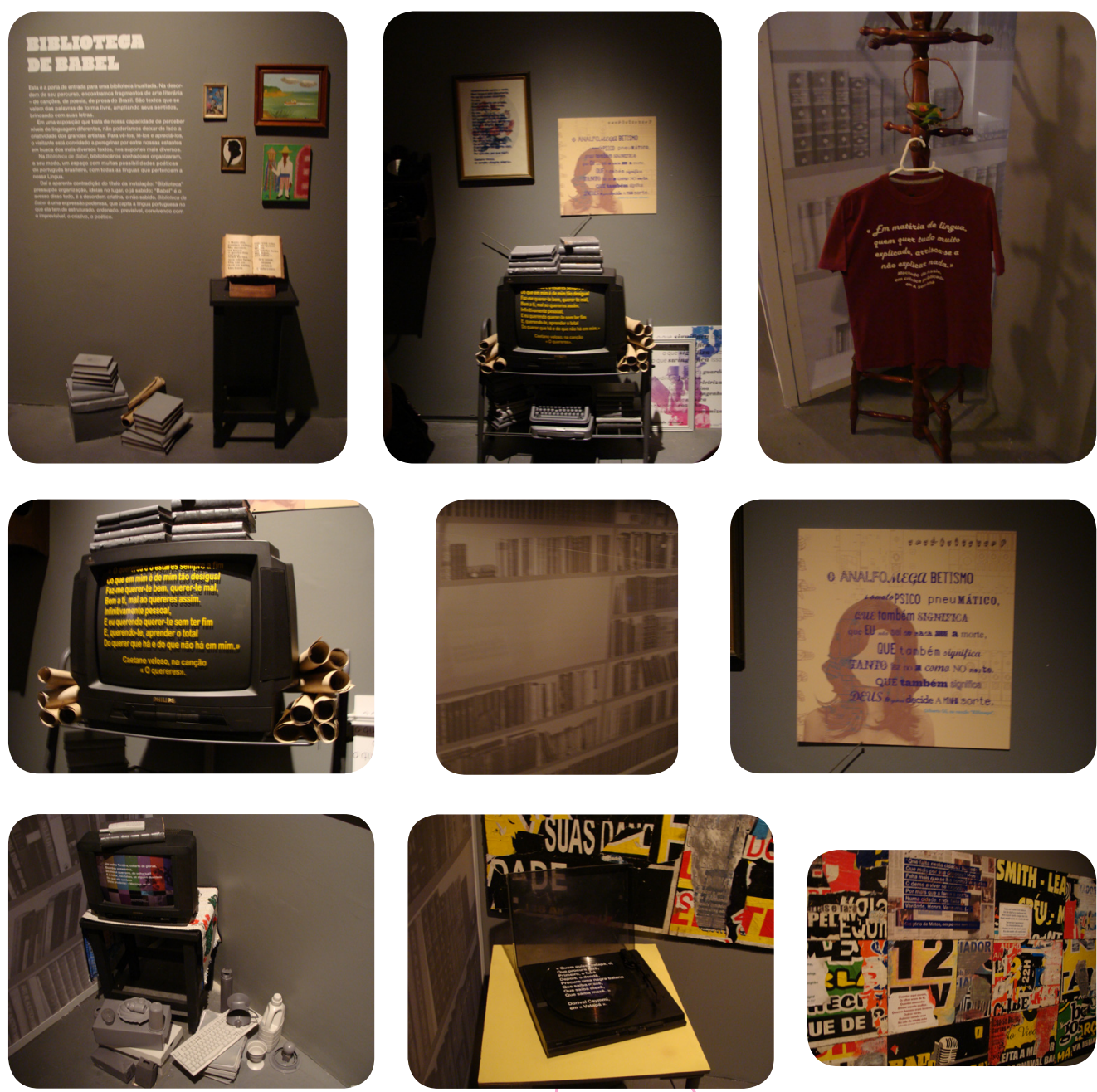

Figuras 16, 17, 18, 19, 20, 21, 22, 23 e 24. Imagens da instalação "Biblioteca de Babel".

Fonte: Acervo dos Autores.
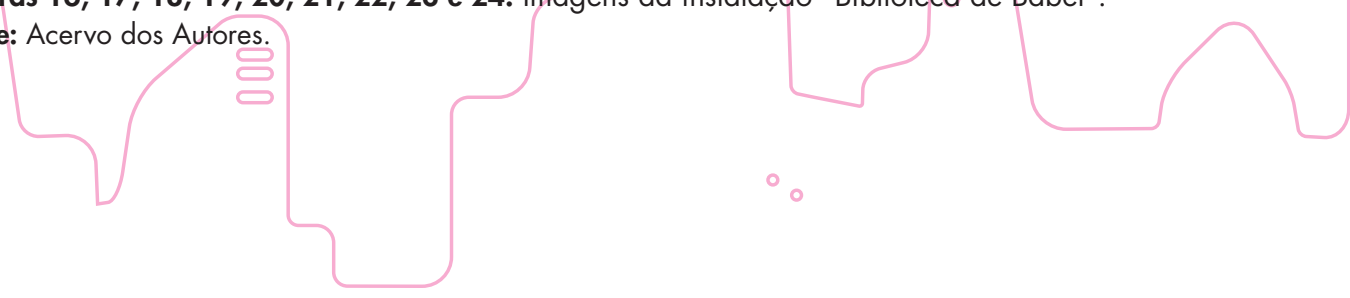


\section{- Norma, a Camaleoa}

Dentro da própria língua, há tensões e conflitos de visão de quatro sistemas: a norma gramatical, a norma lexical, a norma semântica e a norma discursiva.

No vídeo Norma, a Camaleoa, a atriz Alessandra Colassanti, encarna as quatro normas da língua portuguesa ao mesmo tempo, apresentando-as e discutindo-as. $O$ encontro fictício das "Normas" se dá no banheiro do museu, que o visitante observa atrás dos espelhos. Entre um retoque de maquiagem e uma ajeitada no cabelo, elas debatem que, ao operar com as regras em nosso cotidiano, podemos selecionar formas aceitas ou formas rejeitadas pela sociedade. Cada sistema abriga tanto o certo quanto o errado.
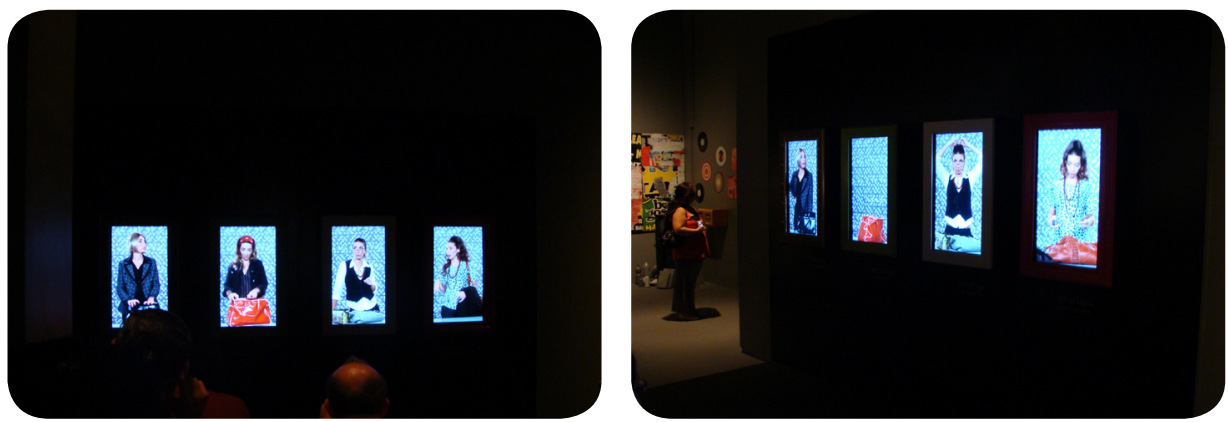

Figuras 25 e 26. Cenas de Norma, a Camaleoa.

Fonte: Acervo dos autores.

\section{- Janelas abertas}

Depois deste mergulho no português brasileiro, o visitante retorna aos amplos espaços sociais onde é praticada nossa língua. Um corredor estreito e final da exposição, traz à tona índices de uma rua de comércio popular e do linguajar praticado nessas ruas, convidando o público a voltar para a vida fora do Museu e perceber a língua de maneira mais generosa, apreciando sua criatividade e mutabilidade.
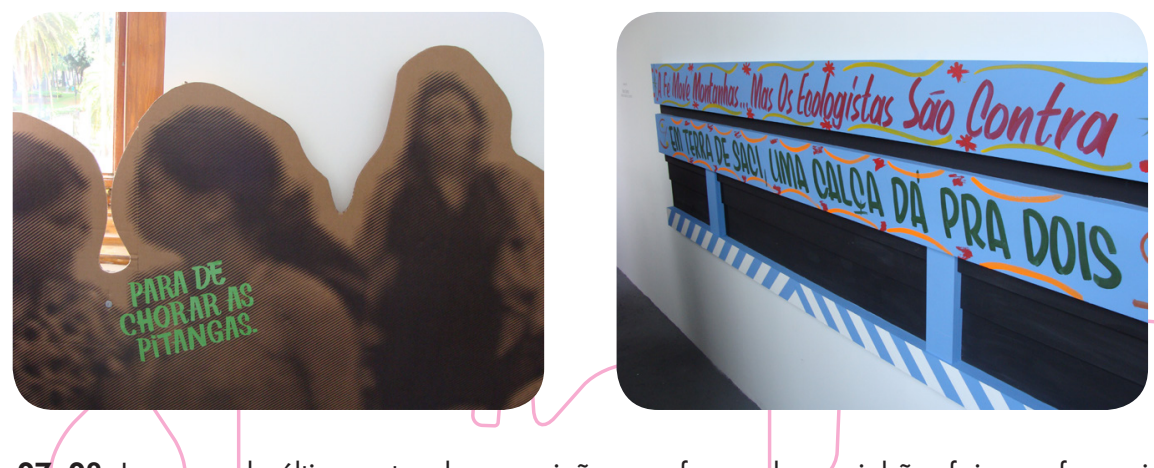

Figuras 27, 28. Imagens do último setor da exposição com frases de caminhão, faixas e frases indicando as mutações da língua portuguesa no cotidiano.

Fonte: Acervo dos autores 

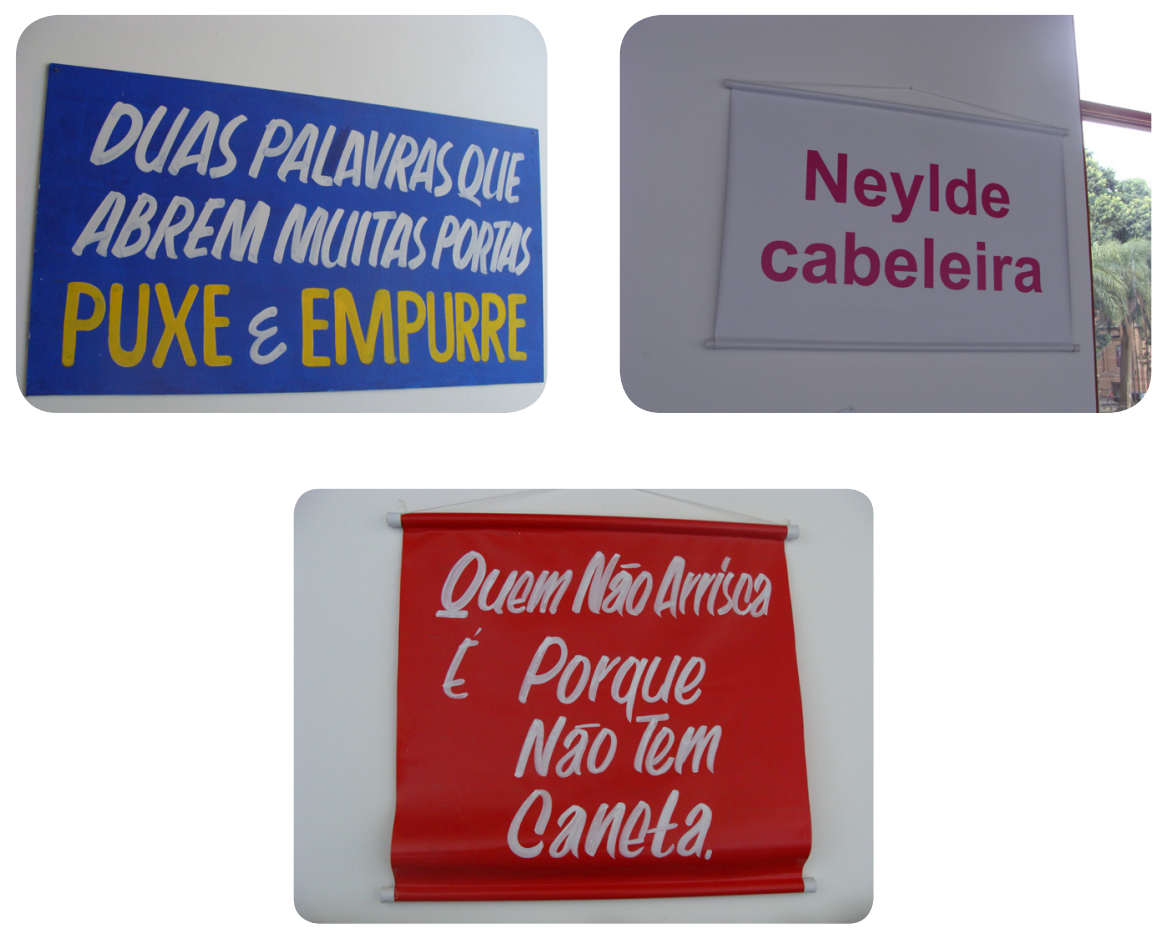

Figuras 29, 30 e 31. Imagens do último setor da exposição com frases de caminhão, faixas e frases indicando as mutações da língua portuguesa no cotidiano.

As instalações são compostas de forma não linear (episódica), por mais que o visitante não siga a ordem sugerida pelo curador, ele poderá fazer o entendimento do espaço expográfico e da mensagem expositiva sem que qualquer tipo de informação seja prejudicada.

\subsection{Wonderlland: ações e parradoxos}

Outra exposição visitada foi Wonderland: ações e paradoxos, realizada no Centro Cultural São Paulo no período de 6 de fevereiro a 25 de abril de 2010.

Nessa exposição foram dispostos no saguão do CCSP dez pontos de exibição multimídia que eram compostos por monitores $L C D$, uma cúpula sonora e um assento para acomodar o espectador, que abrigava também o material gráfico do evento.

Segundo o site do CCSP:
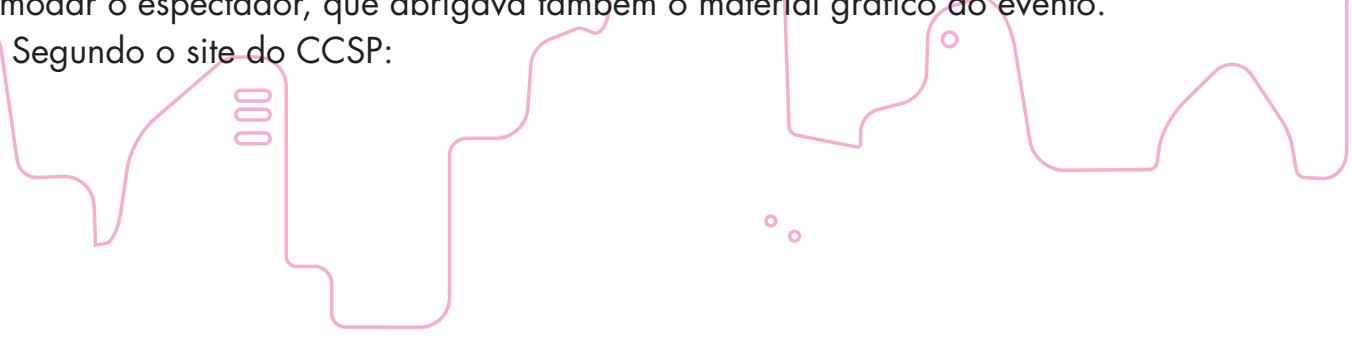
Os trabalhos selecionados para esta exposição se relacionam pelo modo como transformam uma ação em objeto de arte. Da mesma maneira em que o corpo do artista se converte em objeto de arte durante uma performance, as ações exibidas em Wonderland substituem o objeto. Essas ações não necessariamente têm uma finalidade estabelecida ou propósito predeterminado - é possível dizer que elas não têm objetivo, tampouco conduzem a nada. Isso faz com que as obras permitam refletir sobre o sentido do sentido e sua relação com o absurdo. Através desses vídeos, a exposição oferece uma série de paradoxos - contradições - que questionam qualquer interpretação lógica.

As dez obras audiovisuais compreendem uma ação:

- Voyage - artista: Antti Laitinen - ação: Remar

Nessa obra, o artista confecciona uma ilha e rema por um rio/oceano.

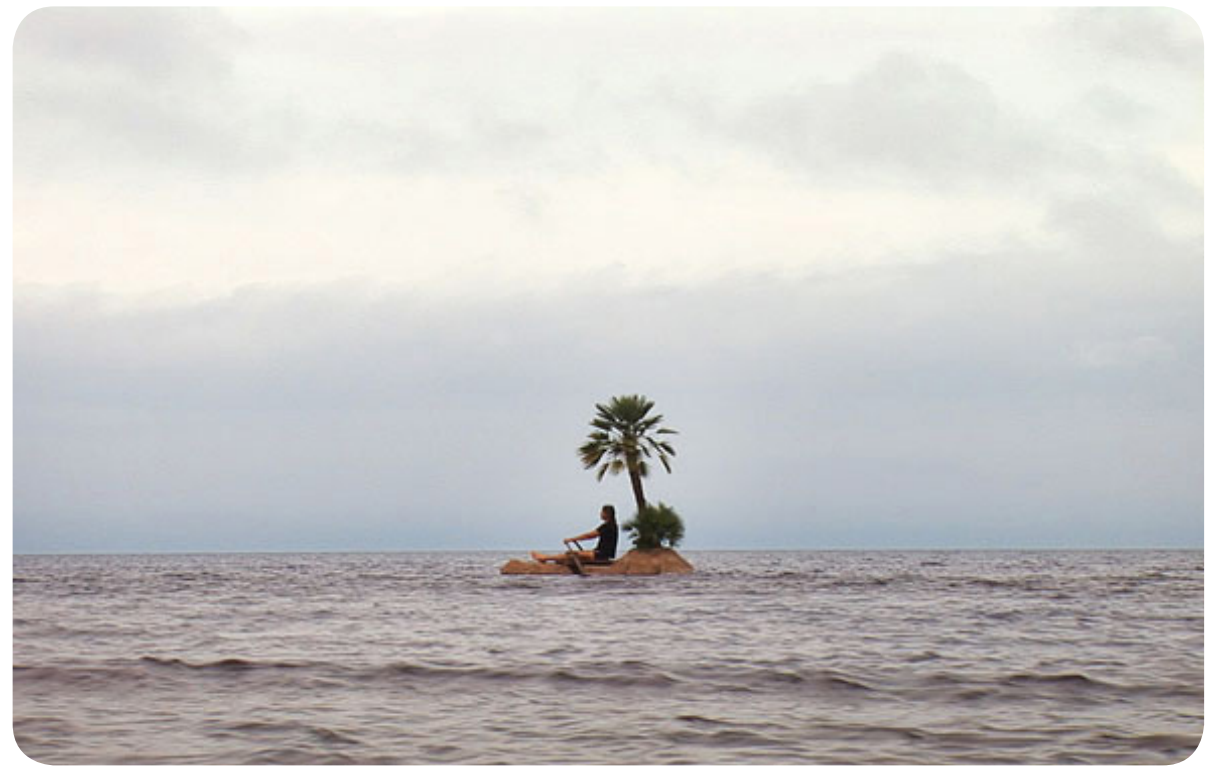

Figura 32. Imagem da obra Voyage

Fonte: http://www.centrocultural.sp.gov.br/projeto_paradas/movimento_exposicoes.htm
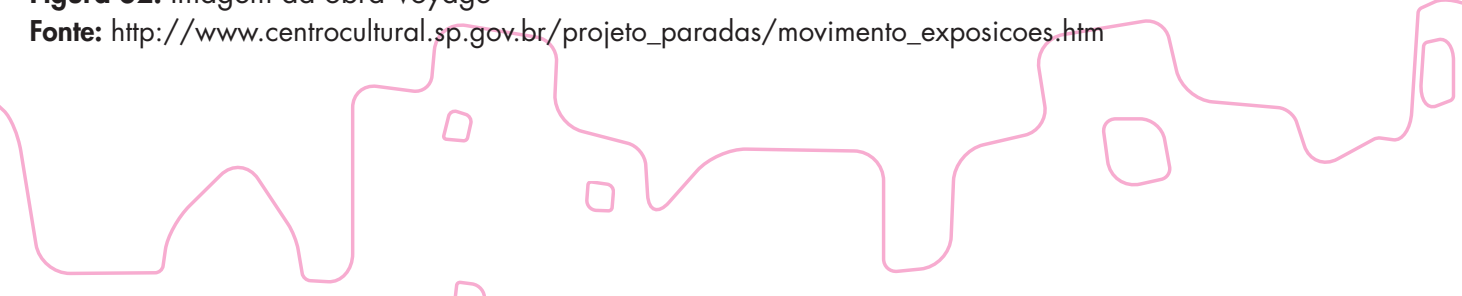
- Hic et nunc - artista: Marilá Dardot - ação: Apagar

Hic et nunc, que significa "aqui e agora", é uma obra onde a artista escreve sobre um quadro branco 72 verbos que descrevem os procedimentos adotados em seus trabaIho. As palavras são escritas e, logo em seguida, apagadas.

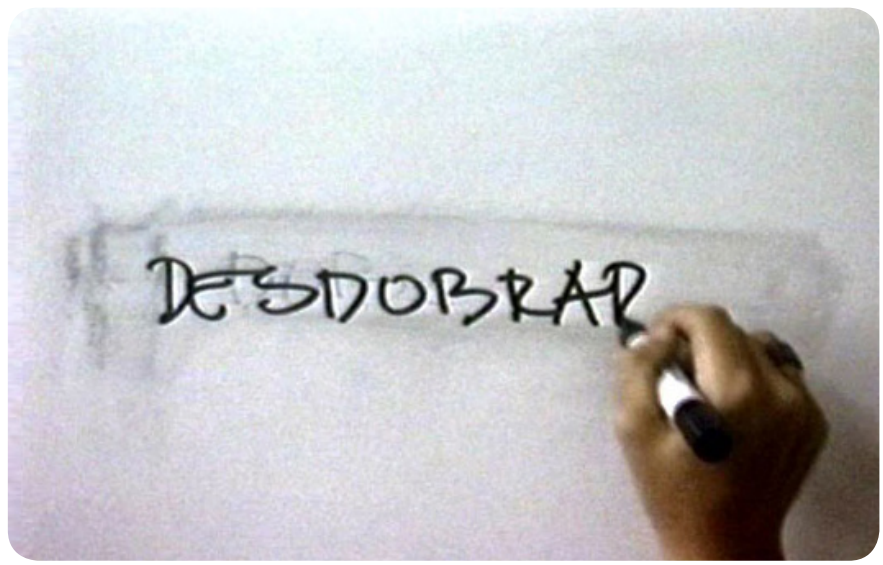

Figura 33. Imagem da obra Hic Et Nunc

Fonte: http://www.centrocultural.sp.gov.br/projeto_paradas/movimento_exposicoes.htm

- Nado y nada - artista: Laura Glusman - ação: Nadar

Uma mulher nada pelo Rio Paraná, porém a obra passa a sensação de que ela continua sempre no mesmo lugar.

Figura 34. Imagem da obra Nado y nada

Fonte: http://www.centrocultural.sp.gov.br/projeto_paradas/movimento_exposicoes.htm
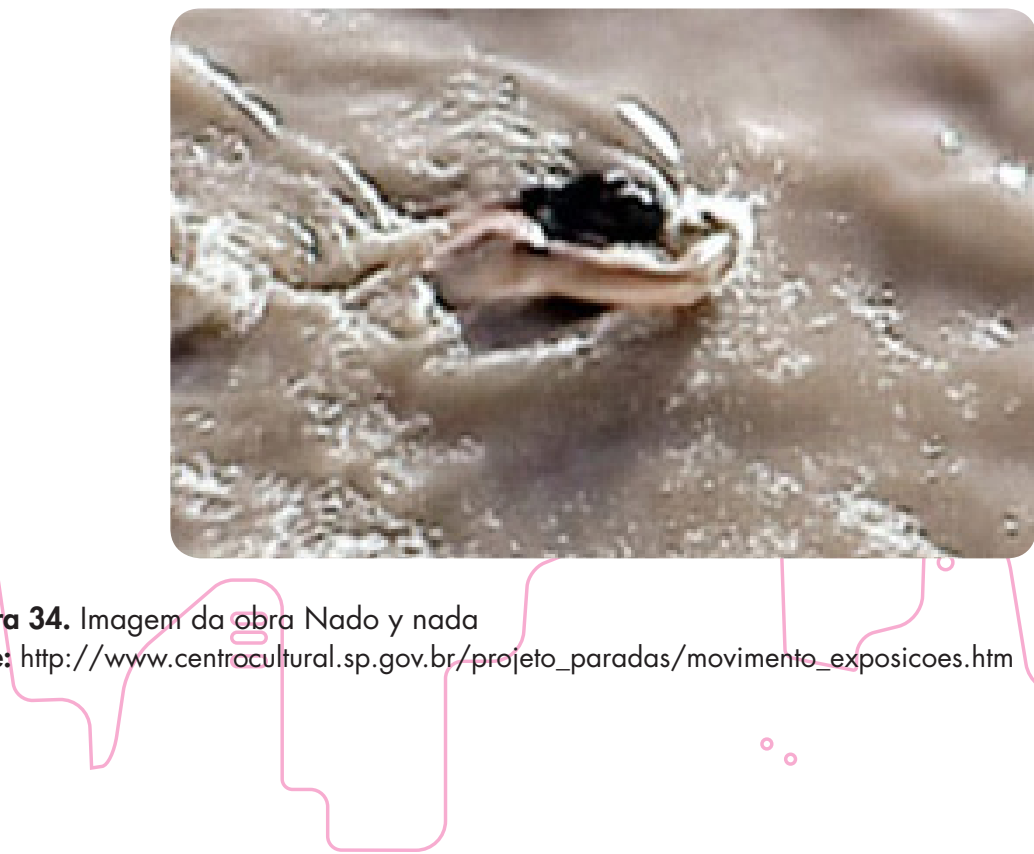
- $\mathbf{4 7 5}$ volver - artista: Cinthia Marcelle - ação: Cavar

Uma escavadeira percorre um trajeto em um terreno de terra no formato de um símbolo de infinito, carregando a terra por toda essa extensão dando a sensação de uma ampulheta gigante.

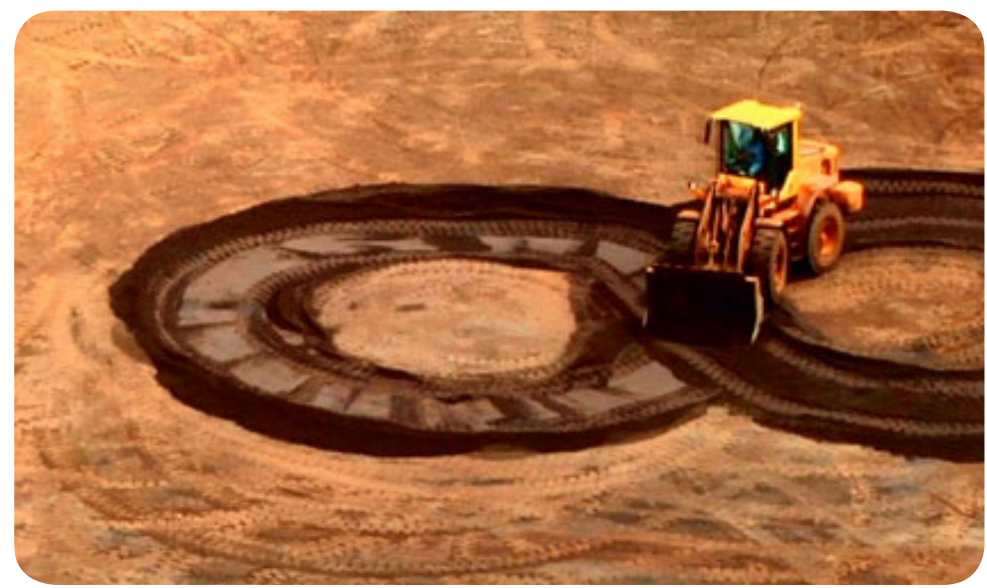

Figura 35. Imagem da obra 475 volver

Fonte: http://www.centrocultural.sp.gov.br/projeto_paradas/movimento_exposicoes.htm

- Flickering - artista: Kika Nicolela - ação: Acender

No instante que a artista apaga e acende um fósforo em um local completamente escuro, ela recria um auto-retrato emocional.

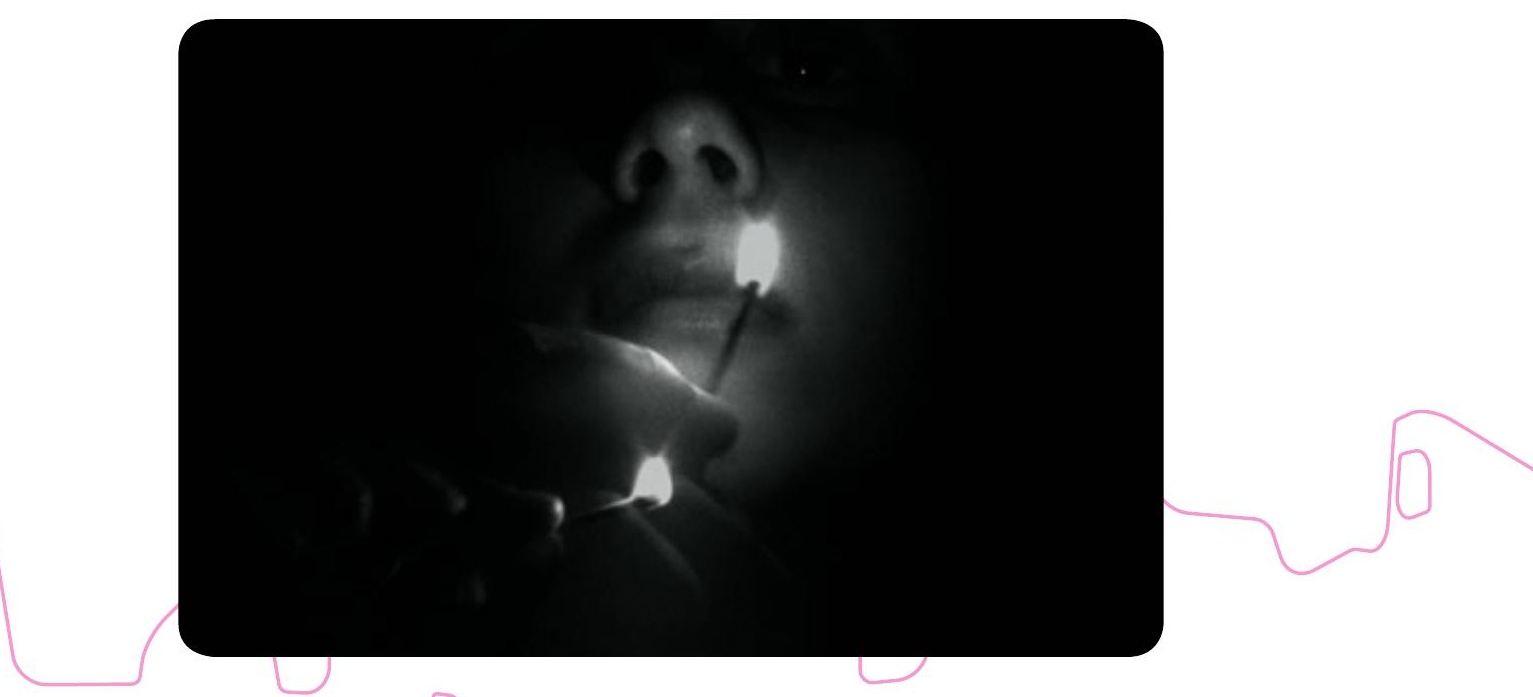

Figura 36. Imagem da obra Flickering

Fonte: http://www.centrocultural.sp.gov.br/projeto_paradas/movimento_exposicoes.htm 
- Vermelho - artista: Renata Padovan - ação: Despejar

A artista despeja gelatina vermelha sobre um campo coberto de neve e depois mostra os vestígios dessa ação quando essa desaparece.

- Ferro, leite e garrafa - artista: Rodrigo Castro - ação: Derreter

Na obra o artista pressiona um ferro de passar roupas sobre uma embalagem de leite. $O$ ferro derrete o plástico e ao mesmo tempo ferve o leite até que os dois sumam.

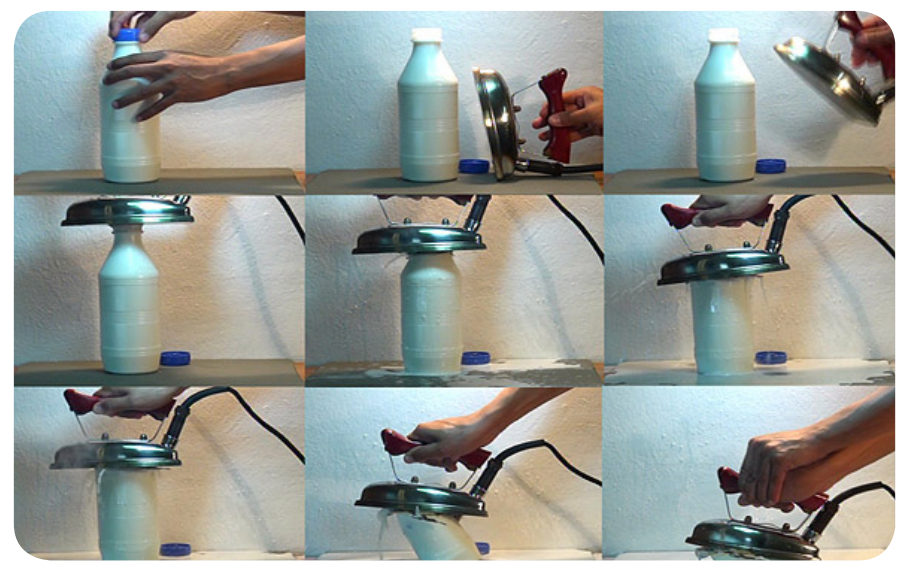

Figura 37. Imagem da obra Ferro, leite e garrafa

Fonte: http://www.centrocultural.sp.gov.br/projeto_paradas/movimento_exposicoes.htm

- Compensação dos erros - artista: Lais Myrrha - ação: Escrever

No vídeo a artista busca realizar um desenho de observação de um relógio digital, porém o relógio está ligado e ela tenta atualizar os números ao mesmo tempo em que eles mudam.
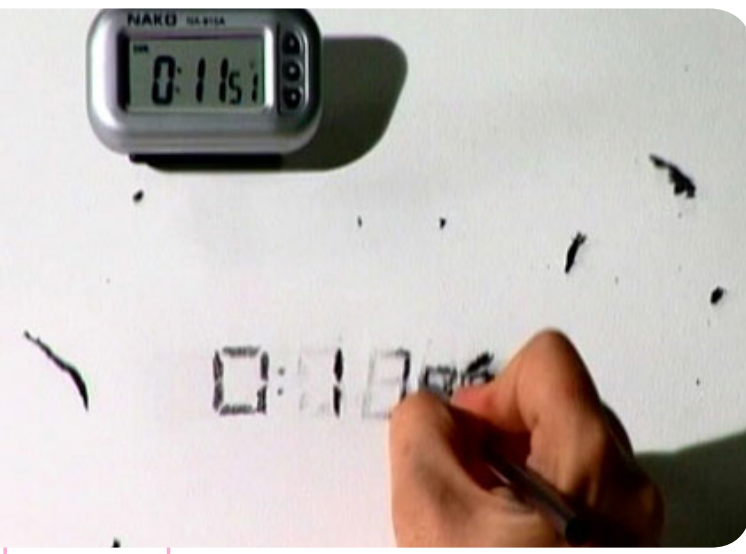

Figura 38. Imagem da obra Compensação dos erros

Fonte: http://www.centrocultural.sp.gov.br/projeto_paradas/movimento_exposicoes.htm 
- Desvios cotidianos - artista: Adriana Aranha - ação: Tomar

De frente a uma mesa, a artista despeja todo o café contido na chaleira dentro de uma xícara, fazendo com que o líquido transborde.

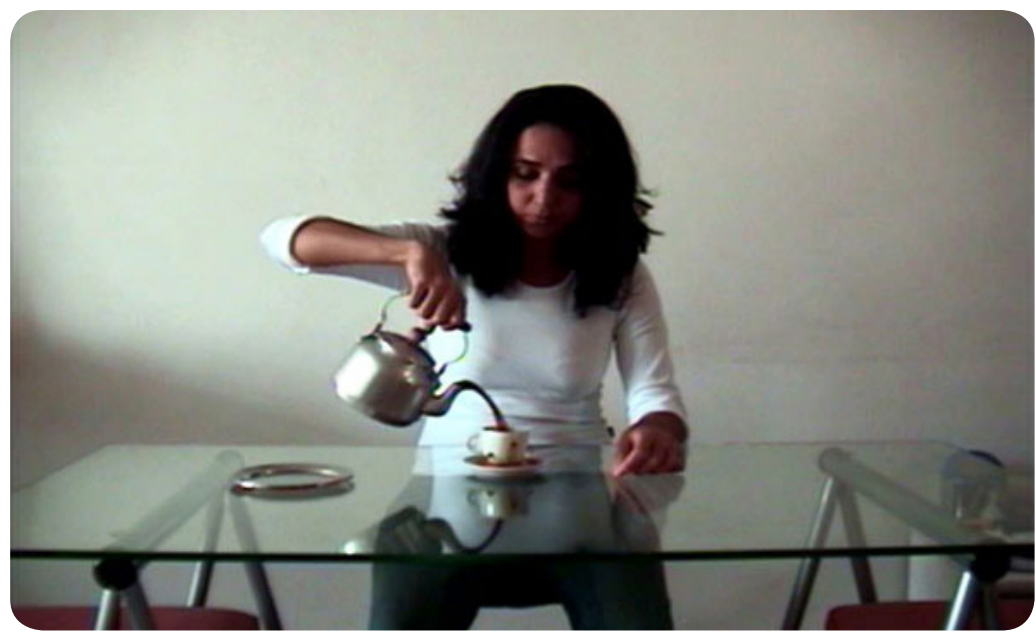

Figura 39. Imagem da obra Desvios cotidianos

Fonte: http://www.centrocultural.sp.gov.br/projeto_paradas/movimento_exposicoes.htm

- It happened near the Angel Tube Station - artista: Paola Junqueira - ação: Encher Com um balde, a artista retira a água de um rio buscando encher uma caixa.

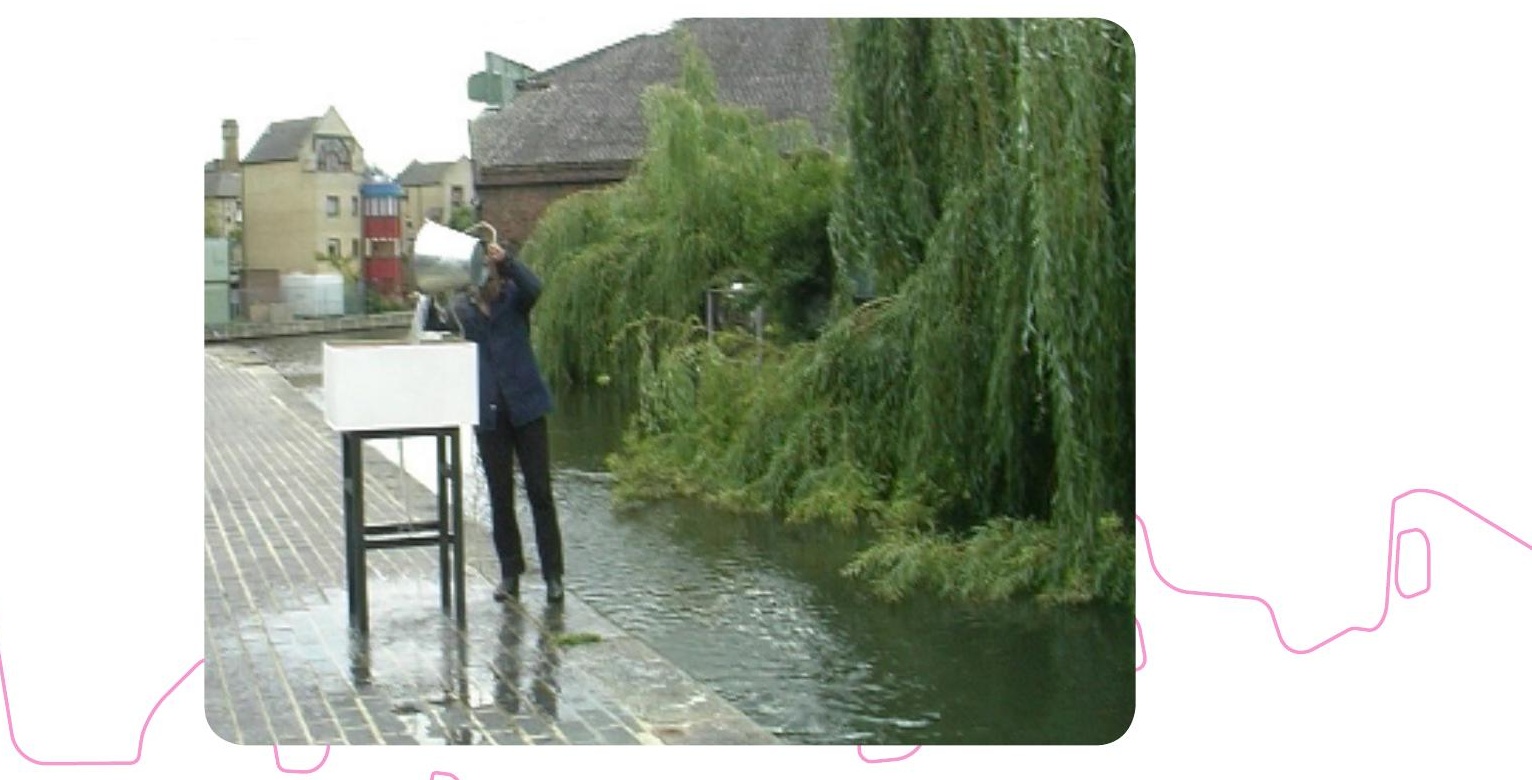

Figura 40. Imagem da obra It happened near the Angel Tube Station

Fonte: http://www.centrocultural.sp.gov.br/projeto_paradas/movimento_exposicoes.htm 
As instalações são compostas de forma não linear (episódica), o entendimento das obras exibidas nas telas apenas são completas quando o visitante toma conhecimento do conteúdo do folder, que descreve de forma sintética a mensagem contida nas obras.

Essas são as exposições que irão guiar nosso raciocínio ao longo desse capítulo. Ambas ocorreram em São Paulo e tiveram públicos-alvo semelhantes.

Outras exposições que ocorreram no circuito foram:

\subsection{Urbann Manners 2 - Artistas contemporâneos da ĺndia}

Com a ideia de revelar as surpreendentes contradições da Índia globalizada a partir de temas como imigração, meio ambiente, poluição, consumismo, gênero, pobreza e perda dos valores tradicionais, os artistas locais Sheba Chhachhi, Atul Dodiya, Anita Dube, Probir Gupta, Subodh Gupta, Ranbir Kaleka, Jitish Kallat, Reena Saini Kallat, Raghubir Singh, Thukral \& Tagra e Avinash Veeraraghavan se expressam pela escultura, pintura e arte em vídeo.

Na vanguarda da arte contemporânea, esses artistas indianos colocam em questão as especificidades de um país em constante modernização, mas que ainda é conhecido pela extrema pobreza e pelas tradições filosóficas e religiosas.

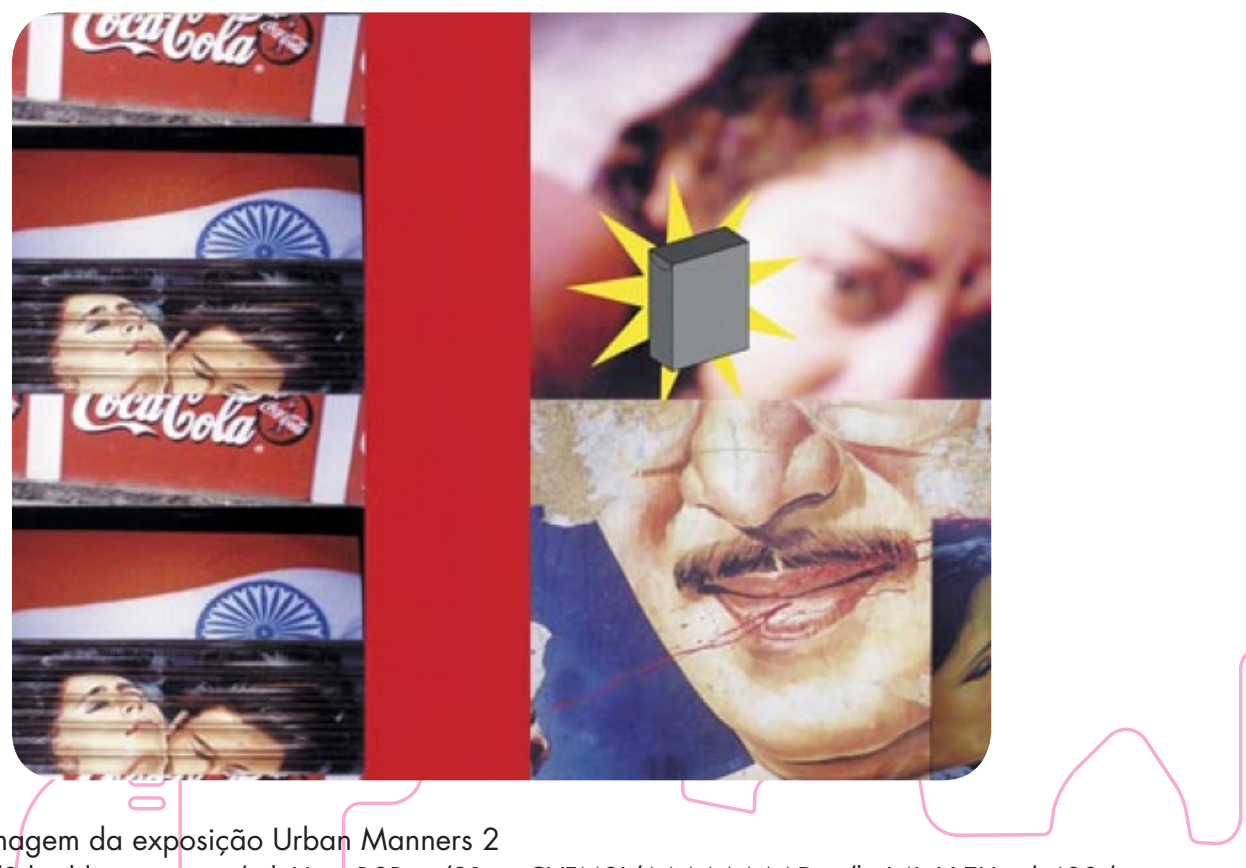

Figura 41. Imagem da exposição Urban Manners 2

Fonte: http://3.bp.blogspot.com/_deHqpxB3Bzg/S1 ccqCVFM8I/AAAAAAAADvs/byL4LcV EUvs/s400/ urban_manners.jpg

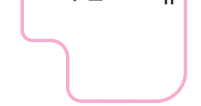




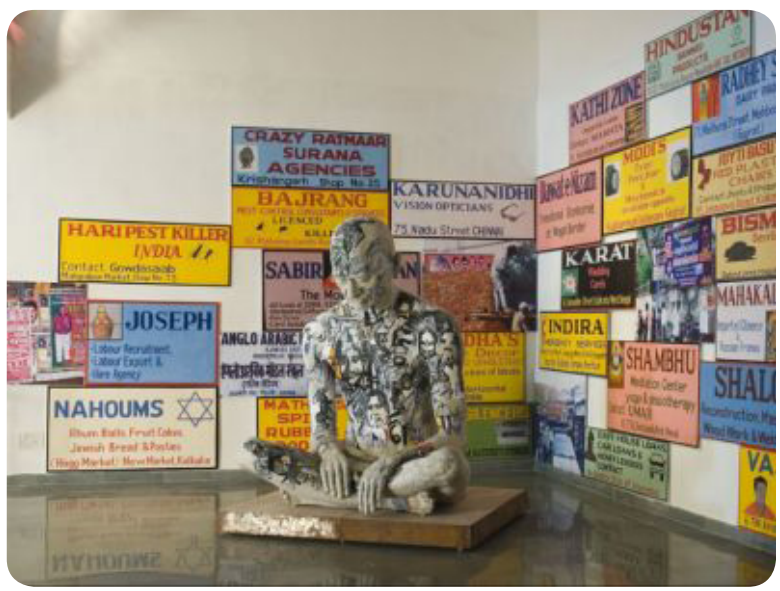

Figura 42. Imagem da exposição Urban Manners 2

Fonte: http://www.opperaa.com/userfiles/image/artes_visuais/2010/02/urban_manners_2.jpg

\subsection{Brava Gente - Tide Hellmeister}

A exposição "Brava Gente" conta a história dos personagens criados por Tide, a partir da observação do cotidiano de passageiros do metrô, do ônibus, dos caminhantes nas ruas. Sua coleção de personagens nasceu quando ele morava na Praça da Árvore, em São Paulo, no percurso que fazia para ir trabalhar na região Central da cidade. Depois, no estúdio, imaginava a vida de cada um e recortava, colava e pintava seus rostos: tristes, bondosos, malandros, egoístas, avaros, generosos, abatidos ou conformados.

Figura 43. Imagem da exposição Brava Gente

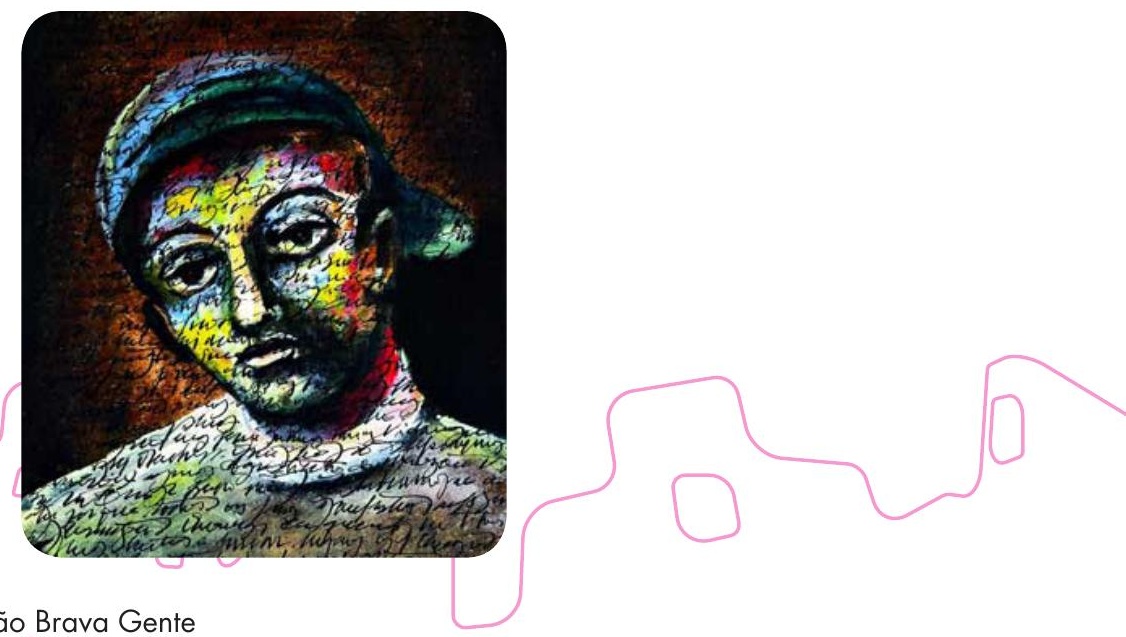

Fonte: http://blogs.cultura.gov.br/Culturaepensamento/files/2010/03/agenda_brava_gente2.jpg 


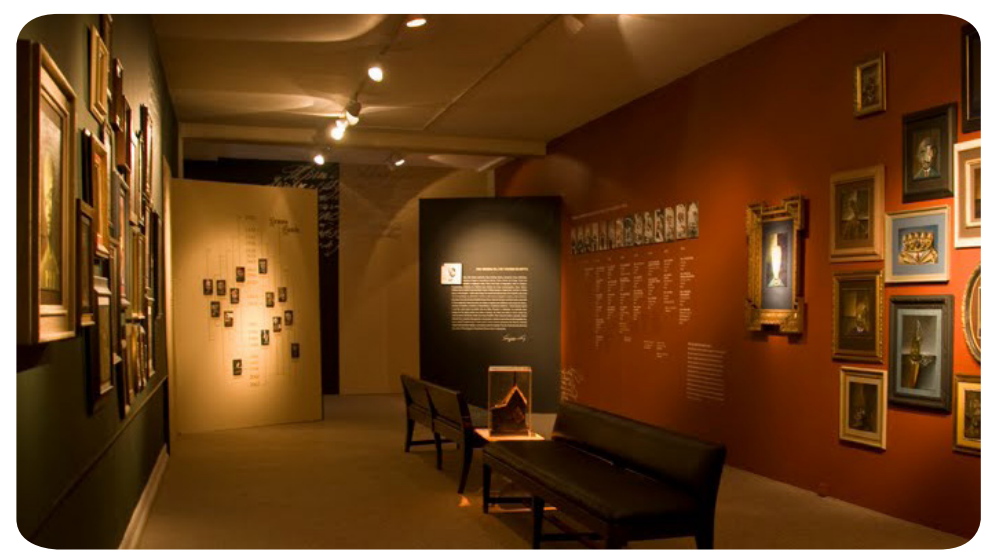

Figura 44. Imagem da exposição Brava Gente

Fonte: http://i2.r7.com/data/files/2C92/94A4/267A/732F/0126/7AF9/D82F/50FD/ExpoTide Hellmeister.jpg

\subsection{Espellhos de Luz e Sombra}

As fontes de inspiração de Irina lonesco são pinturas simbolistas, filmes hollywoodianos, tragédias gregas, poesia decadente, o kitsch sublimado e o sublime consagrado. Em sua obra, a fotógrafa cria paraísos artificiais, expõe a magia do falso luxo, fabrica jogos a partir de múltiplos espelhos imaginários nessa exposição que ocorreu na Caixa Cultural no período de 06 de março à 11 de abril de 2010.
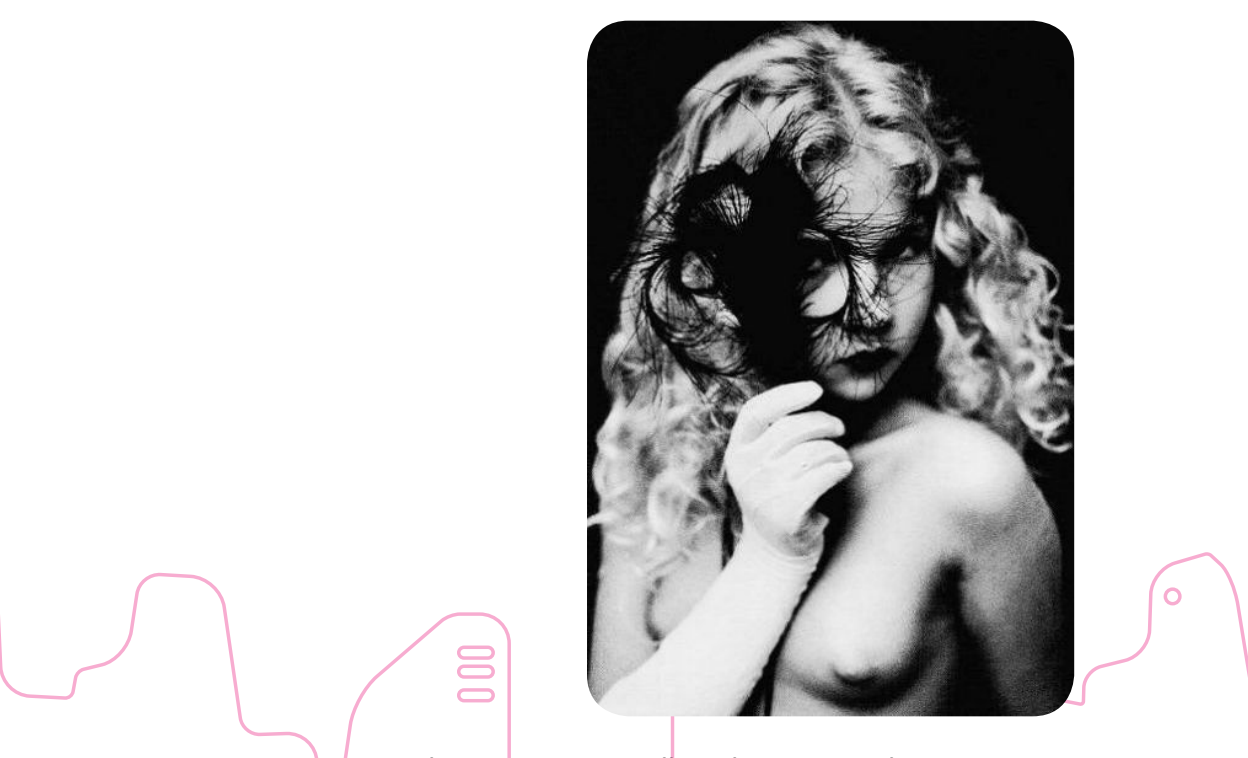

Figura 45. Imagem da exposição Espelhos de Luz e sombra

Fonte: http://www.rioscope.com.br/website/IMG/ipg/irina l.jpg 


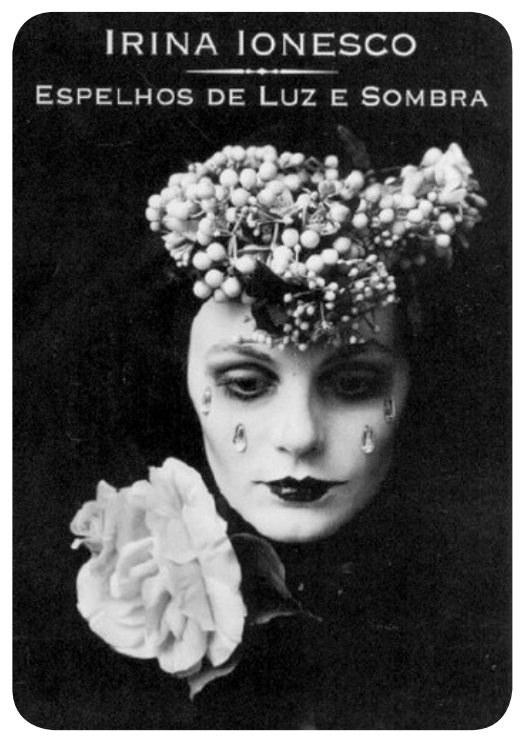

Figura 46. Imagem da exposição Espelhos de Luz e sombra

Fonte: http://www.filmefashion.com.br/blog/arquivos/posts/eva3.jpg

\subsection{Andy Warlhol, Mri. América}

A Estação Pinacoteca reuniu no período de 20 de março à 23 de maio de 2010 as obras do maior ícone da arte pop mundial, com a exposição Andy Warhol, Mr. América que trouxe as obras que o consagraram como as gravuras de Marilyn Monroe e as latas de sopa Campbell's.
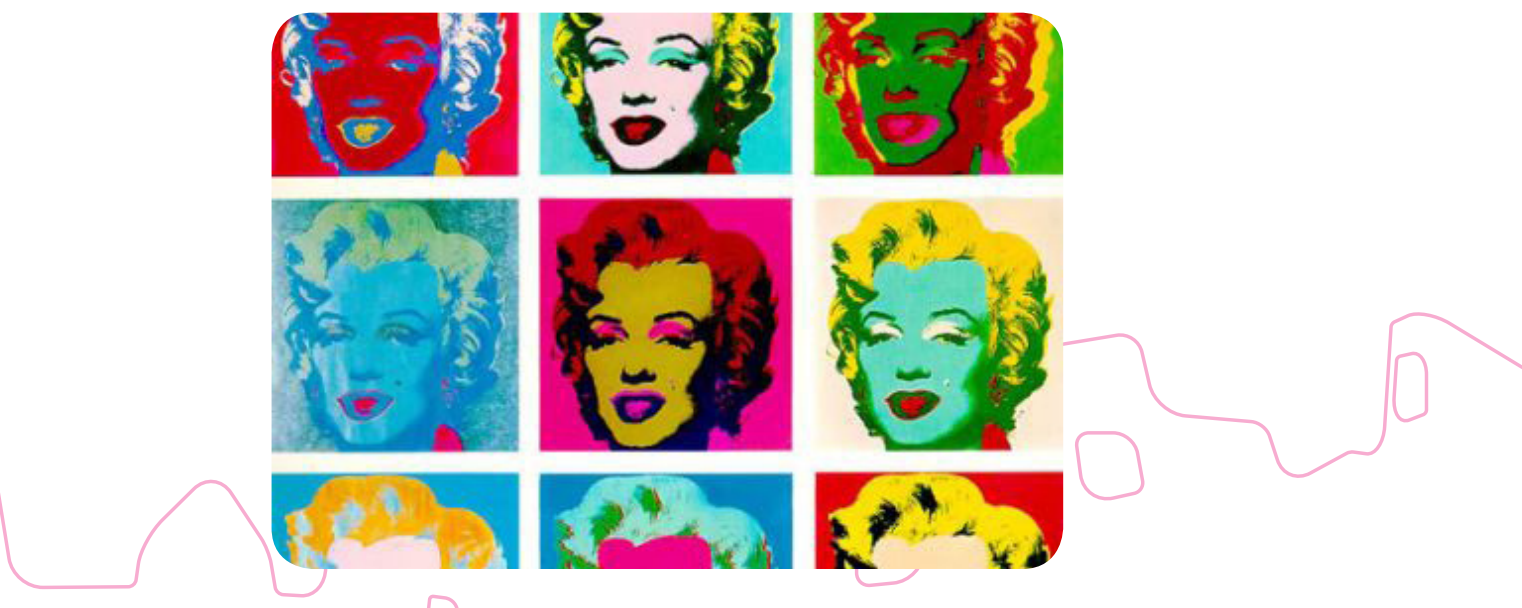

Figura 47. Imagem da exposição Andy Warhol

Fonte: http://www.opperaa.com/userfiles/image/artes_visuais/2010/03/Andy_Warhol_Mr_America.jpg 


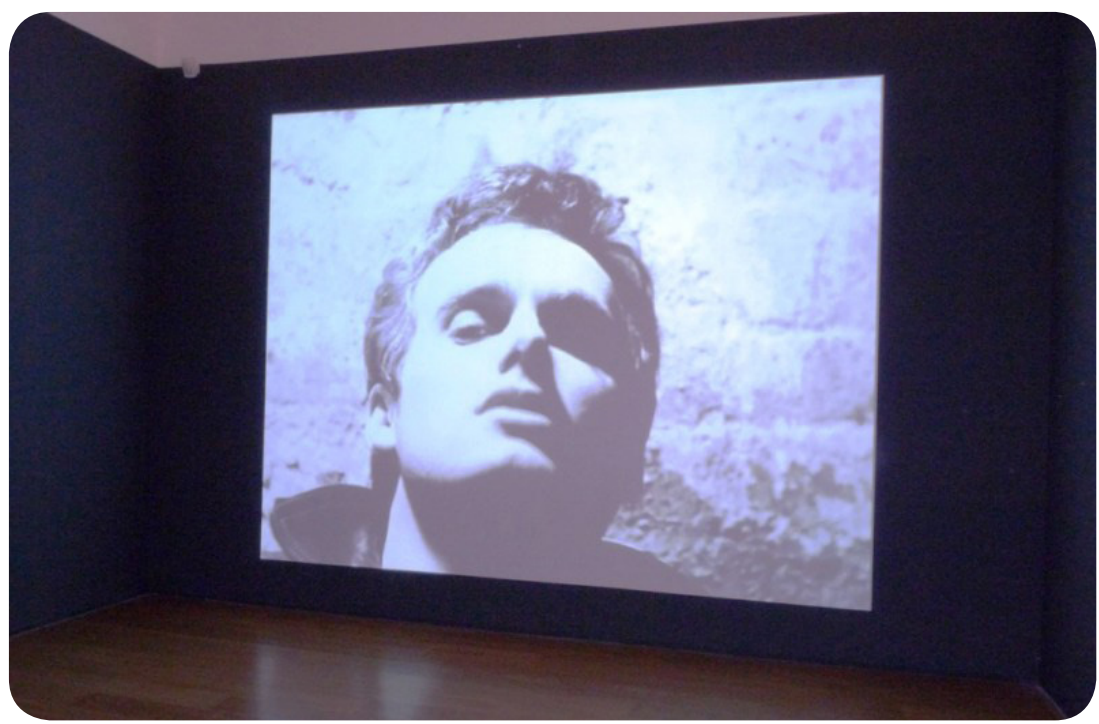

Figura 48. Imagem da exposição Andy Warhol

Fonte: http://artabula.files.wordpress.com/2009/10/p1050366.jpg

\subsection{Follheando: Quatro décadas de livros e revistas de artista na Espanha}

Hojeando/Folheando apresenta cerca de 200 publicações de artistas espanhóis produzidas ao longo de mais de quatro décadas. Dentre os artistas, nomes como Lara Almarcegui, Miquel Barceló, Dora García, Antoni Muntadas e Javier Peñafiel.

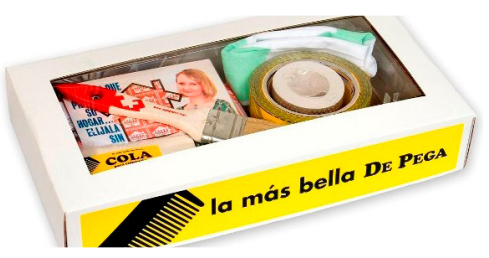

Figura 49. Imagem da exposição Folheando

Fonte: http://danielakutschat.com/blog/wp-content/uploads/2010/03/convite_folheando 1.jpg
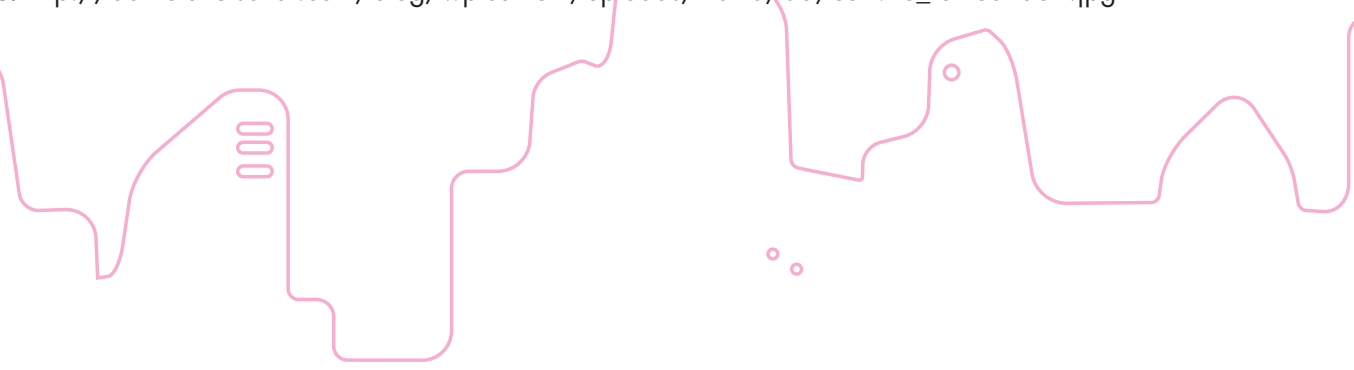


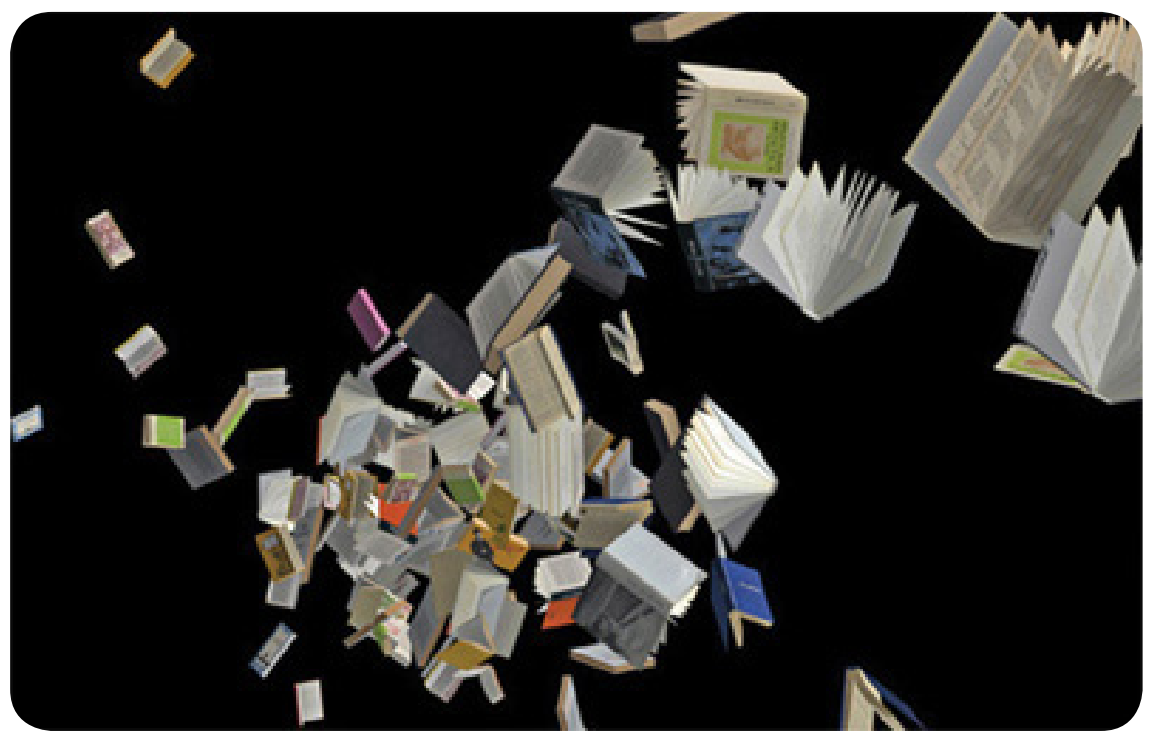

Figura 50. Imagem da exposição Folheando

Fonte: http://ccebrasil.provisorio.ws/system/project_images/37/final/la-mas-bella.jpg

\subsection{Xilogravura: Diálogos entre Técnicas e Gerações}

A exposição apresenta parte dos trabalhos realizados nas oficinas de xilogravura tradicional e em quadrinhos, ministradas, em 2009, na biblioteca, por Eduardo Ver e Ezê.

Figura 51. Imagem da exposição Xilogravura

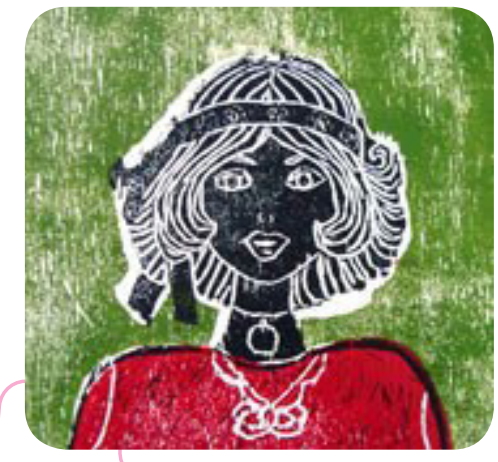

Fonte: http://3.bp.blogspot.com/_zqcMKqA26qc/S4zl1JR8Gyl/AAAAAAAAC7k/YFNgEe HSRgY/s320/ a+xilografia-trabalho_de_maria_lucimar_soares_1267474835.jpg 


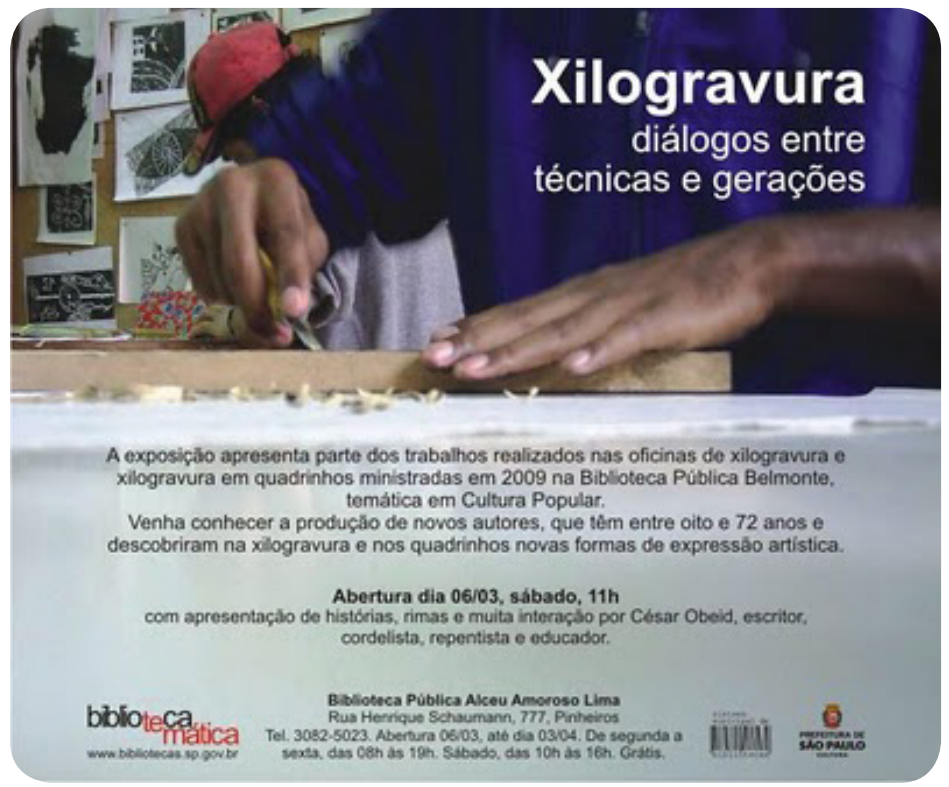

Figura 52. Imagem da exposição Xilogravura

Fonte: http://3.bp.blogspot.com/_X3pVuEQB4YY/S42×3PrzEvl/AAAAAAAABy0/irhZpIMh Dww/s400/ convite+1.jpg

\subsection{Divulgação}

As divulgações de exposições geralmente seguem um padrão. São divulgadas nos sites das respectivas instituições e variam quanto ao grau de importância que as próprias instituições dão aos projetos. Por exemplo, a exposição Menas recebeu além da divulgação no site do Museu da Língua Portuguesa, um hotsite próprio, com ferramentas interativas e que recriam os ambientes da exposição. Já o CCSP efetuou apenas a divulgação da exposição Wonderland em seu site, mostrando rascunhos do projeto e imagens de algumas das obras expostas.

A internet ajudou a alavancar as divulgações de exposições e as instituições passaram a adotar essa ferramenta como meio de comunicação mais veloz, barato e amplo, pois poderá atingir um público muito maior do que com a divulgação impressa. A criação de blogs, e perfis em sites de relacionamentos como Facebook, Twitter e Orkut também são utilizados como meios de divulgação, haja visto que a sociedade atual encontra-se muito mais conectada a essas formas de comunicação. MARTINEZ (2007) reafirma essa importância dizendo que:
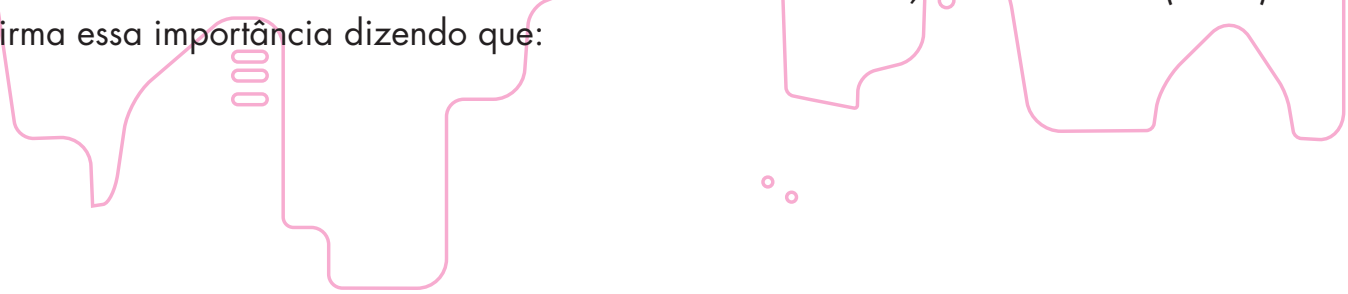
Na mesma medida é também inquestionável a importância de seus subprodutos circulantes: catálogos, folders, sítios na internet, por meio das quais um grande número de pessoas que se encontram distantes da realização do evento em tempo e espaço, tem acesso a um de seus registros.

Muitas instituições optam por fazer a divulgação também em folders internamente e/ou em outras instituições. O trabalho de todo o material gráfico das exposições também varia de acordo com a relevância que a instituição tem para o projeto. Normalmente exposições menores, em instituições não muito divulgadas, não se preocupam muito com a qualidade gráfica desse meio de divulgação por ser um tanto quanto oneroso.

Outro meio impresso que não é muito utilizado são cartazes. Nas exposições visitadas nenhum cartaz foi encontrado fazendo a divulgação na parte externa das instituições, inclusive a exposição Menas que possuía a instalação "Portas abertas" não contava com seus cartazes expostos no saguão do museu. Na parte de dentro, das exposições visitadas, somente na do artista plástico Andy Warhol pudemos ver uma parede com o título da exposição e uma foto trabalhada do artista no saguão da Estação Pinacoteca.

Uma forma alternativa e relativamente barata de comunicação em massa das exposições são os jornais gratuitos de grande tiragem como, por exemplo, em São Paulo os jornais: Destaque SP, Metro e Metrô News. Apenas a exposição Menas teve matérias escritas nesses meios de comunicação.

Os recursos de divulgação são inúmeros, sendo impressos ou digitais, e são de suma importância para o sucesso da exposição.

\subsection{Pontos positivos e negativos}

Muitos pontos puderam ser observados nas exposições visitadas, dentre eles a preparação dos educadores pelas instituições para guiar e ajudar o espectador durante toda a exposição.

Eles são de vital importância não só para solucionar dúvidas dos visitantes durante a exposição, mas os educadores bens instruídos proporão novos questionamentos ao visitante, fazendo o papel de mediador entre o material exposto e o visitante, e dessa forma fará com que o público consiga captar e absorver melhor o conteúdo da exposição.

É importante também que, já que todos os elementos exposifivos como cartazes, folders, sites e ingressos sigam o mesmo padrão gráfico da exposição, os educadores também devem estar trajando uniformes com o tema da exposiçáo e bem identificados com crachás para que o público possa encontrá-los facilmente em caso de dúvida.

Nas exposições visitadas, como pontos negativos, Wonderland e Hojeando/Folheando, todas no CCSP, não possuíam nenhum educador para orientar o público durante as exposições. Tudo era deixado a cargo do único material comunicativo impresso, um 
folder no caso de Wonderland, ao lado das poltronas de exibição, e um livreto sobre uma mesa no caso de Hojeando/Folheando.

A exposição Menas não possuía material impresso de divulgação no local do evento e o catálogo não estava disponível nos primeiros dias da exposição, o que dificultou a comunicação entre os visitantes. Isso gera um grande problema, pois o catálogo depende da foto-documentação da exposição.

Como pontos positivos podemos destacar a interatividade de praticamente todas as exposições visitadas. Umas mais bem trabalhadas do que outras, todas buscaram de certa forma fazer com que o visitante compreendesse o conteúdo da exposição por mecanismos multimídia. Wonderland buscou mostrar as obras por meio de telas e caixas acústicas suspensas; já Menas trabalhou inúmeros e diversos mecanismos de apresentação do material ao público que iam desde vídeos, montagens tridimensionais, leitores ópticos 3D, até faixas e cartazes nas paredes. Hojeando/Folheando buscou mostrar os livros de uma forma não convencional, em molduras de madeira que faziam menção a embalagens de transporte e uma projeção em uma tela nesse tipo de moldura.

A exposição Menas foi a única dentre todas as exposições visitadas onde os educadores estavam trajando uniformes com o tema da exposição, como podemos ver abaixo, e eram treinados a levantar discussões com os visitantes.

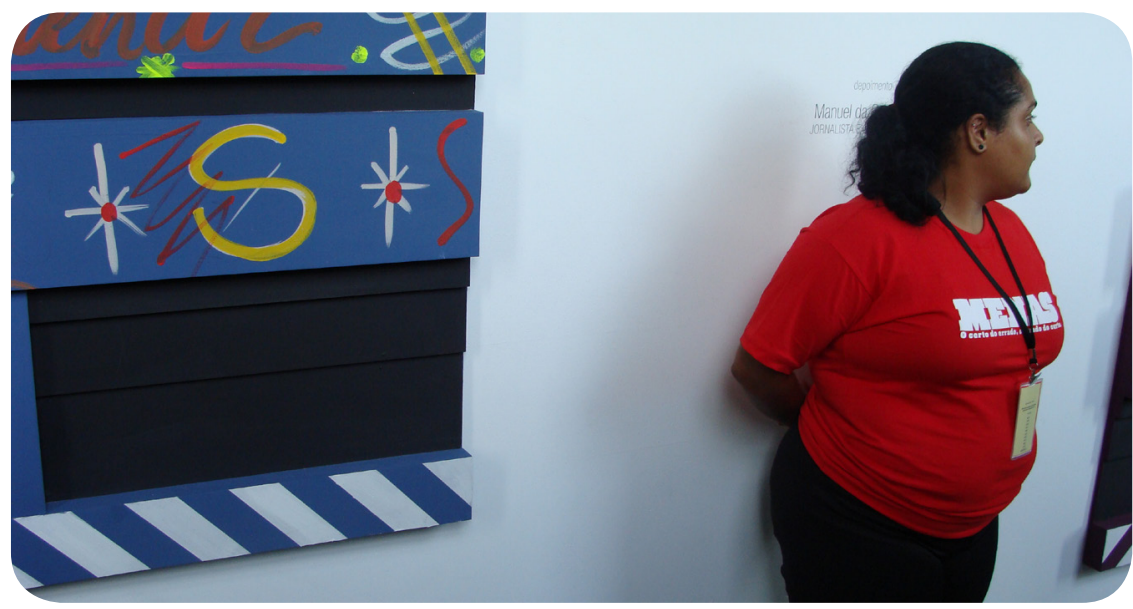

Figura 53. Educadora trajando uniforme na exposição Menas.

Fonte: Acervo dos autores

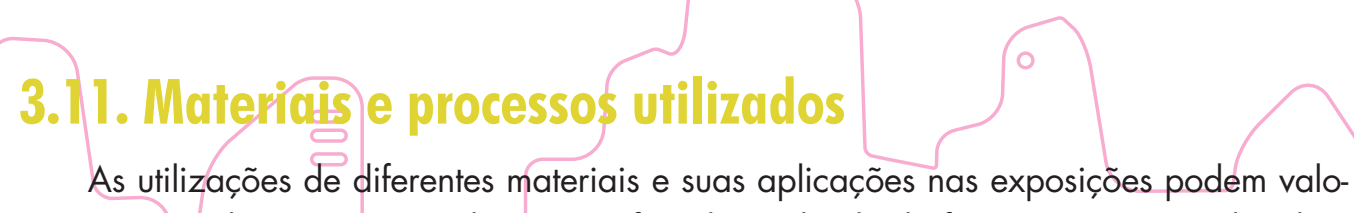
rizar ou empobrecer o conteúdo expográfico dependendo da forma como são aplicados. 
Como o ponto focal de grande parte das exposições visitadas foi a interatividade do expectador com a obra, partindo desse princípio, os materiais a serem aplicados para comunicar a mensagem da exposição foram diversos.

A exposição Menas utilizou uma gama diversa de materiais e aplicações. Na primeira instalação, "Portas Abertas", foram trabalhados banners ao longo do saguão do museu. Na segunda, "Óculos", foram utilizadas placas de acrílico transparente suspensas por cabos de aço e as inscrições que estavam nas placas eram feitas em adesivo. $O$ recurso de adesivagem vinílica foi muito bem explorado nessa exposição. Na terceira, "Os 100 erros nossos de cada dia", o mural foi montado em peças de plástico coloridas e escritas em adesivos. Na quarta, "Jogo do certo e do errado", telas touchscreen proporcionavam maior interatividade entre o expectador e o conteúdo da exposição. A quinta, "Biblioteca de Babel", utilizou diversos tipos de objetos cenográficos que iam desde aparelhos de televisão à toca-discos antigos, quadros, camisetas, boa parte trabalhada seguindo a técnica dos adesivos. Havia também a simulação de uma biblioteca impressa em Lycra. Essa técnica simulou um efeito óptico de biblioteca tridimensional e esse tipo de material uniu a necessidade de transparência, já que por trás de algumas partes da "estante da biblioteca" havia um jogo de luz onde estavam expostos mais materiais como podemos ver abaixo.
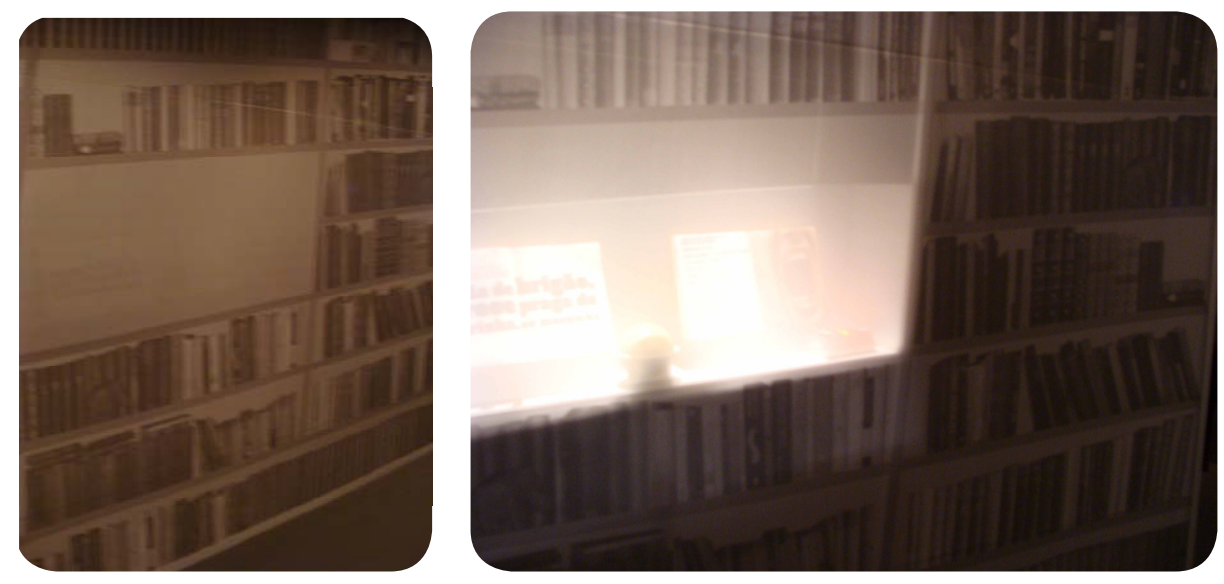

Figuras 54 e 55. Instalação Biblioteca de Babel

Fonte: Acervo dos autores

Já a sexta, "Norma a Camaleoa", dispunha de quatro telas planas na vertical de 42 polegadas onde eram fransmitidas cenas de vídeo. Por último, "Janelas Abertas", trabalhou também uma grande diversidade de materiais e aplicações tais como a simulação de traseiras de caminhão feitas em madeira e pintadas à mão, banners impressos e cartazes feitos à mão mostrando um pouco da cultura vernacular e papel micro-ondulado para simular pessoas em um ambiente cotidiano. 


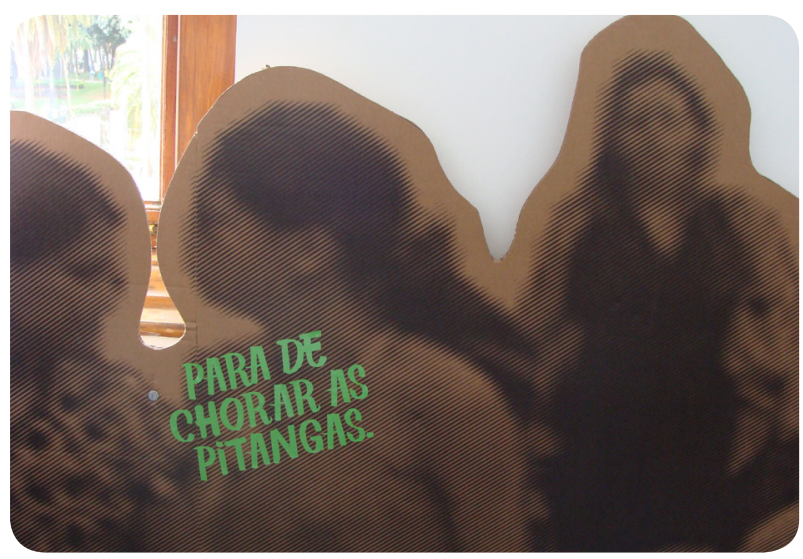

Figura 56. Aplicação do papelão (papel microondulado) e o efeito proporcionado. Fonte: Acervo dos autores

A exposição Wonderland contou com acessórios multimídia audiovisuais como televisores de tela plana e caixas de sons. Cada vídeo possuía uma instalação como nas imagens abaixo:

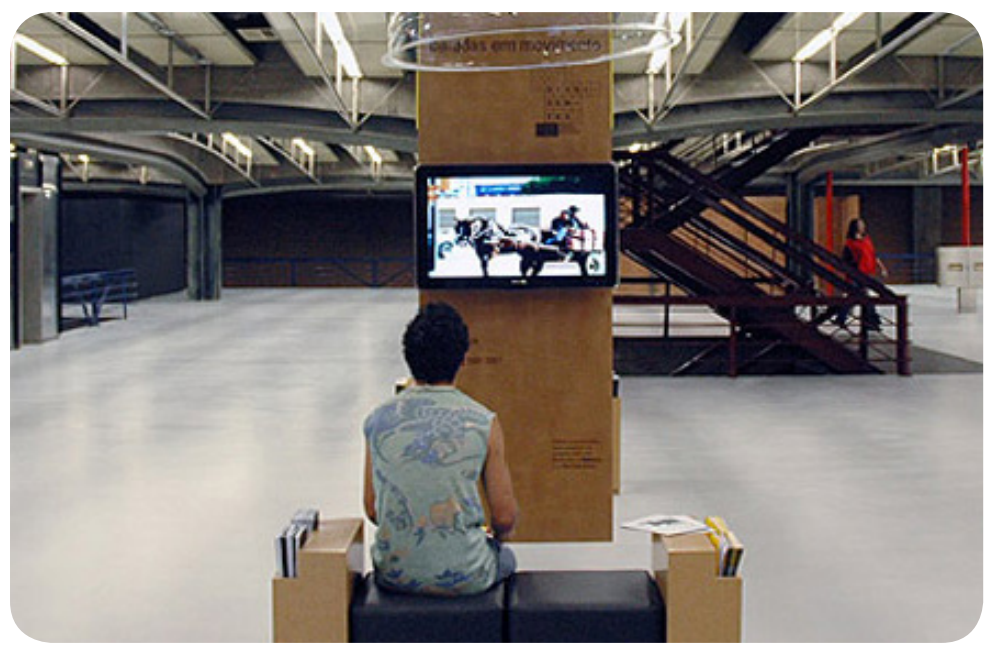

Figuras 57 e 58: Instalações da exposição Wonderland no CCSP. Na parte superior uma redoma acústica de acrílico com uma caixa de som, os assentos com as bases para acomodar os folders nas laterais e, de frente, o painel com a tela e as informações aplicadas na madeira que dá sustentação à tela.

Fonte: http://www.centrocultural.sp.gov.br/projeto_paradas/movimento_imagens.htm
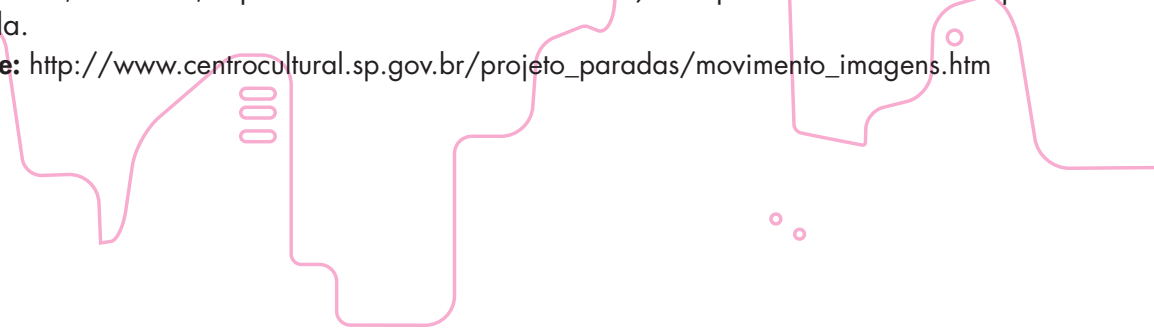


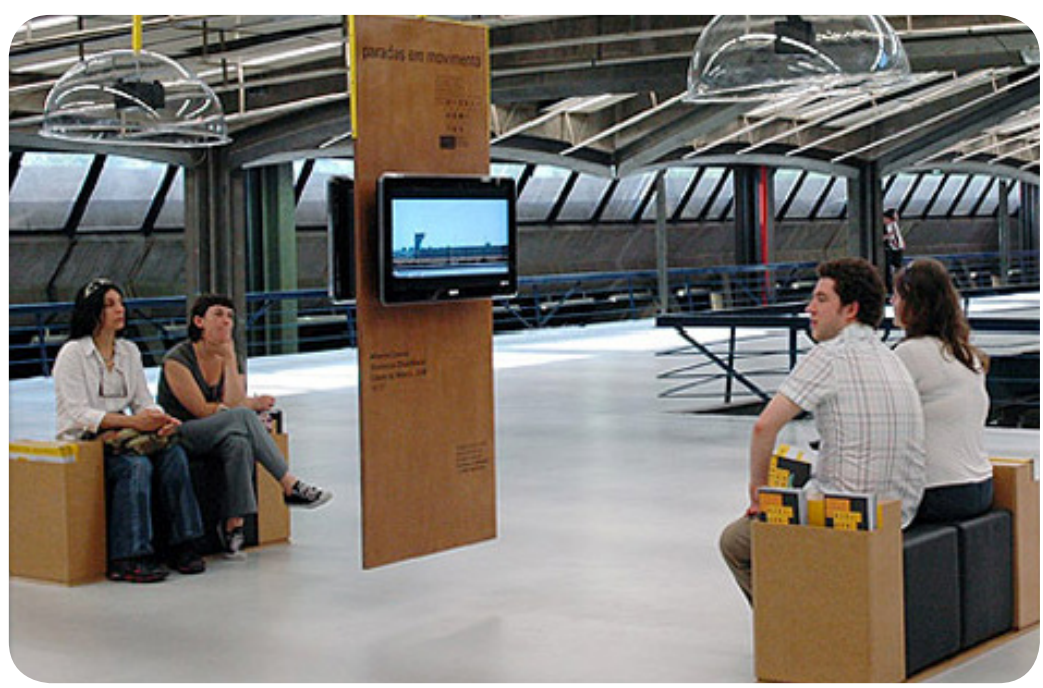

Como pudemos ver nas imagens acima as instalações de Wonderland foram projetadas para que houvesse a interação direta do expectador com a obra, de modo que ele, de certa forma, fizesse parte dela ao ver e sentir o que está na tela, e ouvir os sons dos quais está vendo as imagens por meio do equipamento de som suspenso. Porém, como afirmamos anteriormente, esse tipo de instalação é um tanto falha, pois por mais que o som esteja indo diretamente ao expectador através da redoma de acrílico ainda há a interferência de ruídos externos.

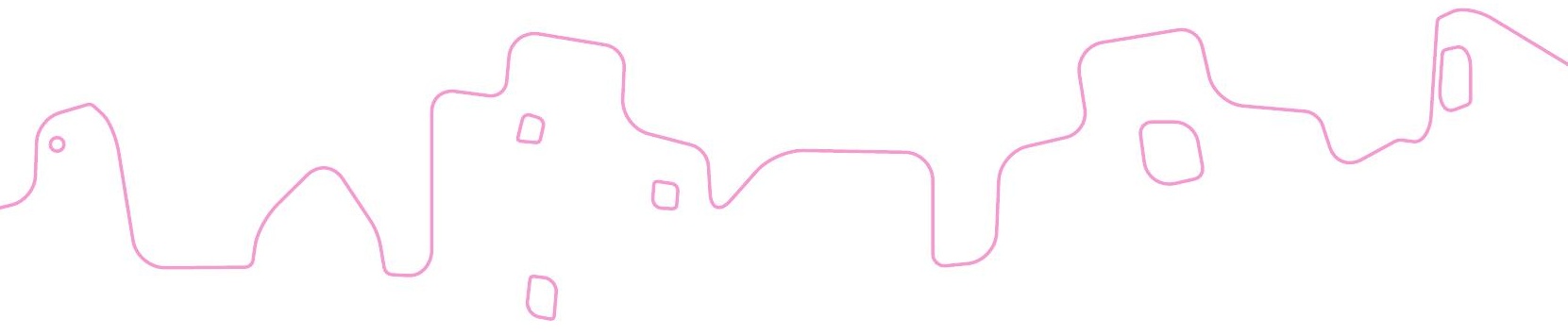




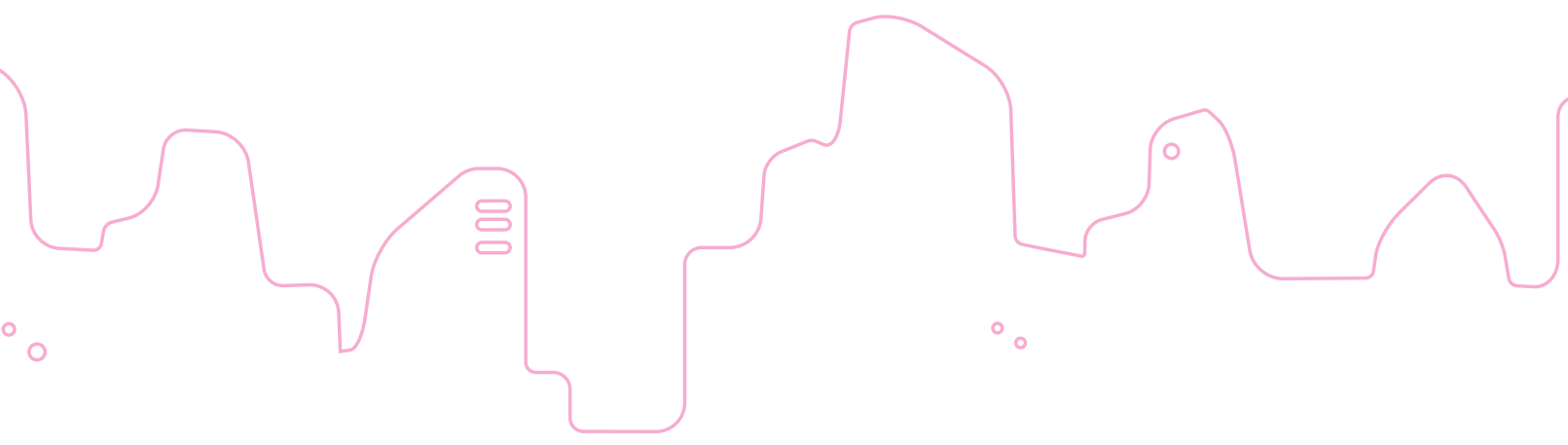

